Review

\title{
The ISO 31000 standard in supply chain risk management
}

\author{
Ualison Rébula de Oliveira ${ }^{a,}{ }^{*}$, Fernando Augusto Silva Marins ${ }^{\text {b }}$, \\ Henrique Martins Rocha ${ }^{\mathrm{c}}$, Valério Antonio Pamplona Salomon ${ }^{\mathrm{b}}$ \\ a Universidade Federal Fluminense (UFF), 783 Desembargador Ellis Hermydio Figueira St Volta Redonda, Rio de Janeiro, 27213-145, Brazil \\ b Sao Paulo State University (UNESP), 333 Ariberto Pereira da Cunha Av. Guaratingueta, São Paulo, 12516-410, Brazil \\ ${ }^{c}$ Universidade do Estado do Rio de Janeiro (UERJ), Rodovia Presidente Dutra Km 298 - Polo Industrial, Resende, Rio de Janeiro, 27537-000, Brazil
}

\section{A R T I C L E I N F O}

\section{Article history:}

Received 8 July 2016

Received in revised form

5 December 2016

Accepted 8 March 2017

Available online 15 March 2017

\section{Keywords:}

Supply chain risk management

SCRM procedures

Systematic literature review

ISO 31000

Analytic Hierarchy Process

\begin{abstract}
A B S T R A C T
Ruptures and interruptions in supply chains (SC) can cause large financial losses and undermine the reputation of firms. In this respect, there is growing interest among researchers in the theme of supply chain risk management (SCRM). SCRM involves analysis carried out in various steps. However, researchers diverge over the number and content of these steps. In light of this problem, the aim of the present study was to analyze whether it is possible to apply the ISO 31000 standard as a systematic procedure for SCRM. And, if so, how the standard can be implemented in the SCRM context, as a framework in a specific company. Through a systematic literature review, we compared and harmonized the risk management steps proposed by researches about SCRM. Additionally we developed a pathway to identify and prioritize which ISO 31000:2009 risk assessment tools and techniques are supposed to integrate a procedure for SCRM, based on the Analytic Hierarchy Process (AHP), exemplified in an automotive supply chain. Based on the research findings, we infer that ISO 31000 can be used beneficially as a standardized method to perform SCRM, as long as tools and techniques are selected according to the company needs and business characteristics.
\end{abstract}

(C) 2017 Elsevier Ltd. All rights reserved.

\section{Contents}

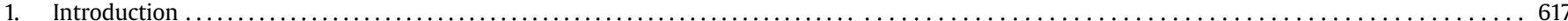

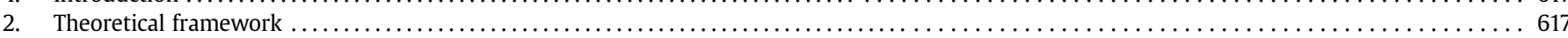

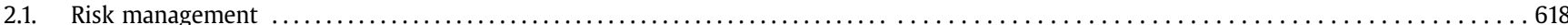

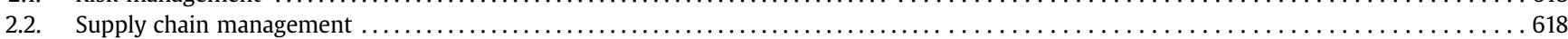

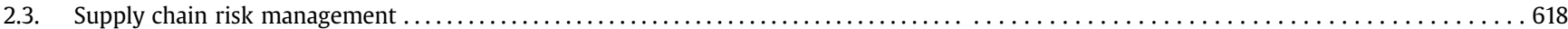

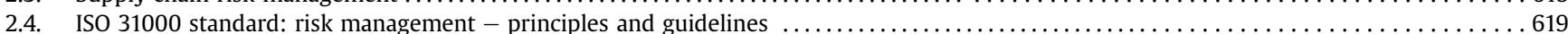

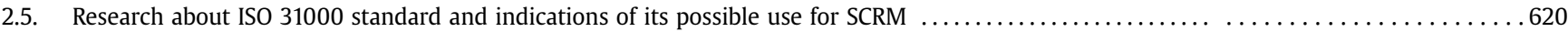

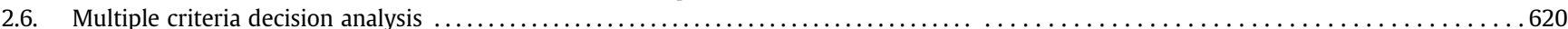

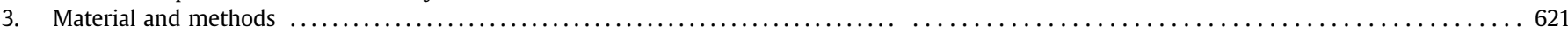

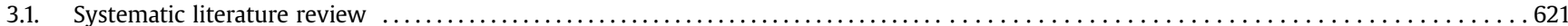

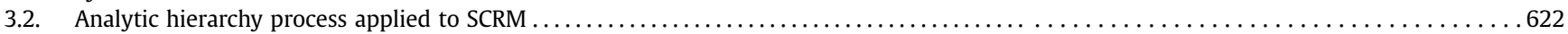

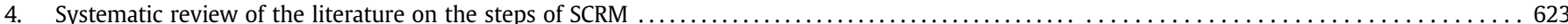

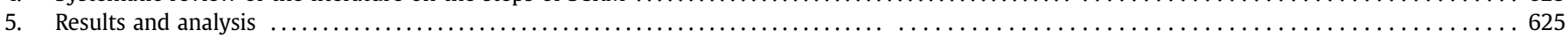

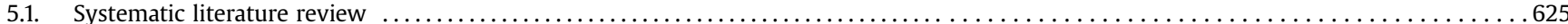

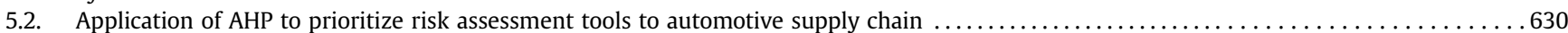

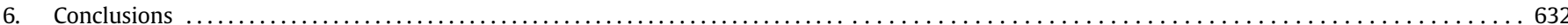

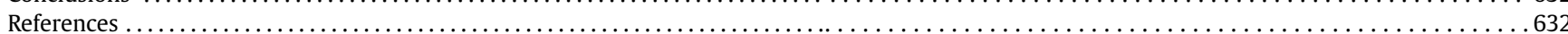

\footnotetext{
* Corresponding author.

E-mail addresses: ualison.oliveira@gmail.com (U.R. de Oliveira), fmarins@feg. unesp.br (F.A.S. Marins), prof.henrique_rocha@yahoo.com.br (H.M. Rocha), salomon@feg.unesp.br (V.A.P. Salomon).
} 


\section{Introduction}

Supply chain problems can generate huge losses for companies, as happened in the last decade with Boeing, Cisco and Pfizer, which suffered losses of US\$ 2 billion, US\$ 2.25 billion and US\$ 2.8 billion, respectively (Hunt et al., 2010). Other notable examples of supply chain interruptions can be found in Sodhi et al. (2012). In the automotive industry, for example, a supply chain failure can cause losses of over US\$100 million per day (Kern et al., 2012).

According to Ghadge et al. (2012) and Colicchia and Strozzi (2012), there are many sources of risks, which can originate within the company (operational risks) or in the external business environment (rupture risks), since the uncertainty of the business climate and the complexity of supply chains increase the likelihood of breakdowns. For this reason according to Christopher and Lee (2004), risk management is an increasingly common element in supply chain management projects.

The aims of managing this type of risk are to minimize the occurrence of interruptions, mitigate their impact on performance and hasten the restoration of the supply chain to its normal state (Hendricks et al., 2009).

Because of the relevance of the theme, the concept of supply chain risk management (SCRM) has emerged as a separate topic of interest, originating from the intersection of risk management and supply chain management (Blos et al., 2009), as illustrated in Fig. 1.

The overall aim of SCRM is to increase the resilience of the supply chain (Pujawan and Geraldin, 2009). It has emerged as an important element in managing supply chains, aiming to identify potential sources of risks and suggest suitable measures to mitigate them, as stated by Singhal et al. (2011) and corroborated by the majority of other researchers interested in the theme.

However, there is a lack of consensus among researchers as to the steps that should be included in SCRM, both regarding their number and the actions involved. For example, Wu et al. (2006), Khan and Burnes (2007), Oehmen et al. (2009) and Singhal et al. (2011) advocate that SCRM should be carried out in a process with at least three steps, which differ in their procedures according to the three research groups. Other authors (Hallikas et al., 2004; Kleindorfer and Saad, 2005; Manuj and Mentzer, 2008; Tummala and Schoenherr, 2011) argue for different procedures, with more than three steps. At the upper extreme, Ritchie and Brindley (2007) defend the conduction of seven steps for supply chain risk management.

Based on this lack of consensus among the researchers regarding the steps that should be applied for SCRM, the following question arises: Is it possible to adopt ISO 31000:2009 as the framework for a standardized SCRM process? This standard was launched in 2009 by the International Organization for

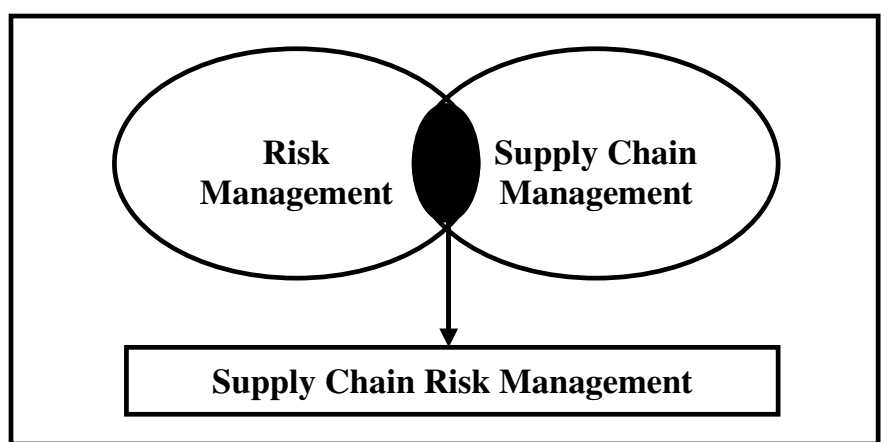

Fig. 1. SCRM as the intersection of Supply Chain Management and Risk Management. Source: Blos et al. (2009).
Standardization, for the purpose of standardizing risk management in general, under the name of "Risk Management: Principles and Guidelines". Therefore, a secondary question that comes up is: if the ISO 31000 can be adopted as a framework, how can such standard be implemented in a specific company, since it is a generic standard?

The justification for choosing that standard is the fact that, as noted by Ataseven et al. (2014), in recent decades a significant number of organizations throughout the world have obtained ISO 9000 and ISO 14000 certification of their processes, in the first case regarding quality control and in the second regarding environmental responsibility (due to growing concern about the environmental impacts of business activities) (Pawliczek and Piszczur, 2013).

As a matter of fact, the latest version of ISO 9001 and ISO 14001 explicitly require to organization integrate risk management in the business practice: in ISO 9001, version 2015, preventive actions were replaced by the concept of "risk-based thinking", a systematic risk evaluation.

The main objective of this article is to propose a pathway to companies develop their procedures to manage risks in supply chains, based on ISO 31000, Section 5.4 (Risk evaluation process) recommendations, under the assumption that the ISO 31000 standard can be used as a systematic process for supply chain risk management. The evaluation would be based on comprehension of the risk management steps that have been covered by researchers interested in SCRM, and by analyzing the correspondence of these steps with those of the risk management process proposed in Section 5.4 of the ISO 31000 standard (i.e. Risk assessment).

Our specific objectives are: i) to identify the SCRM steps proposed in the literature; ii) to classify the SCRM steps that have the same purpose, but are given different names by each author or research group; iii) to compare the resulting SCRM steps with those of the ISO 31000 standard, to enable refuting or endorsing the application of that standard for SCRM; iv) to propose a general procedure to select the risk management tools and techniques listed in ISO 31010:2009 to be used in a SCRM.

The literature content was obtained from a systematic review of the articles published from 2004 to 2015 that address the steps of SCRM, indexed in the Web of Science and Scopus databases. To the application of the general procedure proposed to the automotive supply chain, we adopted the judgment of five experts from companies of this sector in Brazil, analyzed and prioritized through the use of Analytic Hierarchy Process - AHP (Saaty and Shih, 2009).

This is a relevant research problem, for at least three reasons: $i$ ) studies about SCRM are still incipient (Lavastre et al., 2012; Narasimhan and Talluri, 2009), particularly in developing countries like Brazil (Blos et al., 2009); ii) studies about SCRM are rapidly growing in the area of logistics (Colicchia and Strozzi, 2012; Wieland and Wallenburg, 2012; Singhal et al., 2011); and iii) supply chain problems can cause huge losses (Hunt et al., 2010; Kern et al., 2012; Sodhi et al., 2012).

The article is organized into six sections including this introduction. Section 2 examines the basic theoretical underpinnings, while the third section addresses the methodological aspects, followed by Section 4, with a comprehensive literature review; Section 5 presents and discusses the results; and Section 6 sets out the main conclusions and some suggestions for future research.

\section{Theoretical framework}

This section briefly examines some concepts of SCRM, the ISO 31000 standard, and introduces the Multiple Criteria Decision Analysis area, to facilitate understanding of the themes addressed in this study. 


\subsection{Risk management}

Risk management has emerged as an important factor in management and control decisions (Ritchie and Brindley, 2007), widely applied in areas such as economics, insurance and manufacturing, among others. While the word risk applies to uncertain events, possible hazards or damages, or other undesirable consequences (Harland et al., 2003), which can be expressed by means of a probability, management denotes the organized actions or activities to control these occurrences. So, risk management can be understood as a structured process to minimize or mitigate the effects of risks (Wang and Hsu, 2009), or a proactive process of decision making that aims to minimize the consequences of negative future events, by identifying potential risks, analyzing them and planning the responses necessary for their monitoring and control (Zafiropoulos et al., 2005; Mabrouki et al., 2014).

Generally a risk management process involves four steps, in this order: 1) identification of the risks; 2) evaluation of the risks; 3 ) choice and implementation of actions to reduce the likelihood of risks and minimize the effects if they occur; and 4) monitoring of risks (Hallikas et al., 2004). There appears to be a consensus in the literature regarding this overall process (Tuncel and Alpan, 2010), although some researchers advocate fewer or more steps for its achievement.

Tuncel and Alpan (2010) discuss the purpose of each of these four steps, as follows:

- The first step is to identify risks, to help develop a common understanding of future uncertainties, recognized as future risks, to prepare to face them effectively.

- The second step is risk assessment, which means attributing probabilities to events involving risk and identifying their consequences.

- The third step is to define the risk management actions to be implemented. These actions can be, for example, reactive (when a pre-identified risk really occurs) or proactive (actions to mitigate risk by reducing the probability of occurrence or the degree of the consequences).

- The fourth step is to monitor the risk, to detect the impacts of risks that occur and the effectiveness of the countermeasures taken.

\subsection{Supply chain management}

According to Hahn and Kuhn (2012), the supply chain (SC) is formed by external suppliers, the internal processes to produce products or render services, and customers. Due to its high relevance to any business, based on the need to obtain inputs to meet demand and the many events that can interrupt it, Wu et al. (2006) state that the supply chain cannot be taken for granted. Fig. 2 depicts a simplified SC model.

According to Rangel et al. (2015) and Ritchie and Brindley (2007), for adequate integration of the companies that make up the supply chain, there is a need to share processes, both of the organizations that supply all types of raw materials and other inputs and those that distribute the finished products, thus transcending the central firm.

As customers become increasingly demanding regarding product quality and levels of service, and the global economy becomes more open, supply chains are becoming broader and more complex, including with respect to distinct business cultures involved (Juttner, 2005). This requires actions for supply chain management (SCM), which according to Kleindorfer and Saad (2005), has become a key part of the business model, where each "link" must be managed to strengthen the "connection" along the entire network.

Lambert and Cooper (2000) define SCM as management of the multiple relationships that occur along the supply chain, to optimize these intra- and inter-organizational relationships as well as to assure the quality of the processes of all the members of the SC.

For Rao and Goldsby (2009), SCM consists of strategic and systematic coordination of the traditional functions and transactions inside and outside a company, with the objective of improving the performance of the SC as a whole. Complementing this definition, Trkman and Mccormack (2009) contend that SCM is a set of multifunctional and multidisciplinary activities that deal with not only the physical and tangible attributes and activities, but also the behaviors and intangible aspects. They further consider that SCM emanates from a relationship and proactive integration among the various members of the SC.

According to Ritchie and Brindley (2007), only rarely do companies operate with simple linear supply chains. The majority of firms operate through a huge set of channels, both upstream and downstream, involving suppliers of inputs, service providers and end consumers. As framed by Pfohl et al. (2010), the mere relationship among these "actors" causes risks to all those involved, so it is not sufficient only to analyze the vulnerabilities of the central firm (producer). Instead, attention must be paid to the potential "domino" effects that can spread to all the actors in the SC.

To examine those effects, at the beginning of the 2000s the first studies appeared on supply chain risk (SCRM), as covered in the next topic.

\subsection{Supply chain risk management}

Supply chains involve a multitude of areas and participants, including various links, making them vulnerable to the influences of uncertain endogenous and exogenous factors of all those

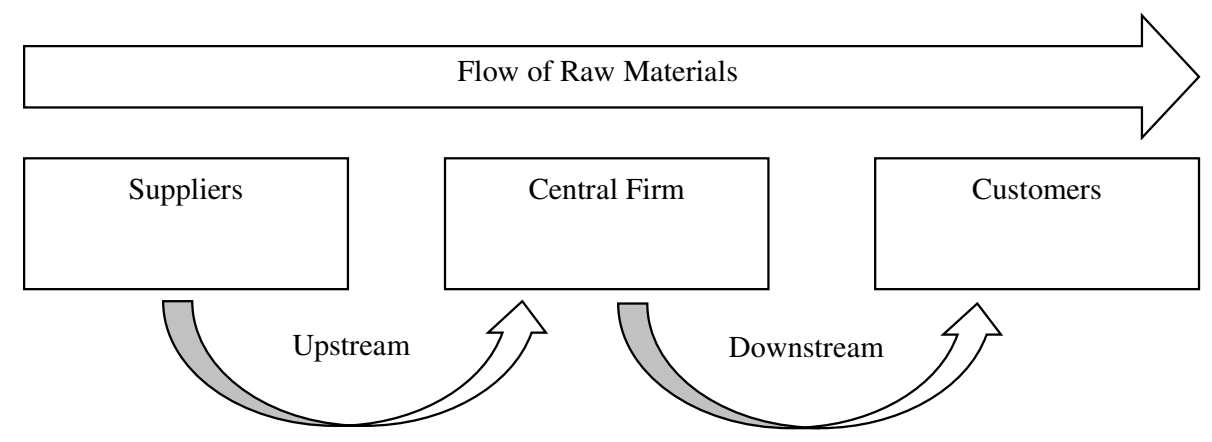

Fig. 2. Supply chain model.

Source: Authors based on Hahn and Kuhn (2012) 
involved in the chain (Guo, 2011). In this environment, the probability of failures is high, requiring contingency plans to avoid ruptures in the chain that harm the business (Tummala and Schoenherr, 2011).

According to Ghadge et al. (2012), the risk of a SC can be broadly defined as the exposure to an event that causes disturbances, affecting the efficient management of the SC. These risks, as put by Manuj and Mentzer (2008), can be classified as quantitative or qualitative. Quantitative risks include understock, overstock, obsolescence and insufficient availability of components and materials in the SC. Qualitative risks include lack of the proper precision or reliability of components and materials in the chain.

Further according to Manuj and Mentzer (2008), the sources of risk can be divided into supply risks, operating risks, demand risks, information security risks, macroeconomic risks, political risks, competitive risks and resource risks. The first four of these (supply, operations, demand and information security) are specifically associated with supply chains, since they can interrupt the operations of supply and/or distribution.

Hunt et al. (2010) argue that the risks inherent to supply chains have an exogenous element for each participant, since each firm that composes a determined SC has its own objectives and motives, which can clash with those of the other firms in the chain. For this reason, their management is complex (Chopra and Sodhi, 2004), since this includes not only the central firm itself, but all the upstream and downstream partners in the chain.

According to Guo (2011), SCRM boils down to how to control the factors that can have negative effects on the normal functioning of the SC, to improve its reliability. Besides this, SCRM has a strong influence on the stability of the dynamic cooperation among the chain's partners, so it is important to the performance of all their operations (Xia and Chen, 2011).

Therefore, the objective of SCRM is to identify potential sources of risk and implement appropriate measures to avoid or restrict the vulnerability of the SC (Singhal et al., 2011). This means controlling the factors that can cause negative effects on the normal functioning of the SC, improving its reliability (Guo, 2011).

Various authors (Harland et al., 2003; Hallikas et al., 2004; Zsidisin et al., 2005; Wu et al., 2006; Ritchie and Brindley, 2007; Wagner and Bode, 2008; Rao and Goldsby, 2009; Jia and Rutherford, 2010; Tummala and Schoenherr, 2011; Wieland and Wallenburg, 2012; among others) have proposed SCRM models for the purpose of managing risks in supply chains, by reducing the vulnerability and assuring continued functioning of the SC. For Jia and Rutherford (2010), for example, SCRM basically consists of: i) defining the concepts of risk and adverse consequences; ii) evaluating the sources of risk; iii) monitoring the risk factors; and iv) minimizing them. For Tummala and Schoenherr (2011), in similar form, SCRM also involves four steps: i) risk identification; ii) risk evaluation; iii) proposal of strategies to accept, transfer, reduce or mitigate risks; and iv) risk monitoring.

\subsection{ISO 31000 standard: risk management - principles and guidelines}

The ISO 31000 standard summarizes risk management into seven steps, as depicted in Fig. 3 and discussed next (ISO, 2009a,b).

1. The process of communication and consultation covers the existence of plans for communication among the parties responsible for implementing the risk management process and the interested parties. It is a relevant step because its purpose is to assure that all those involved in the process understand the grounds on which decisions will be made and the reasons why specific actions are required. Besides this, the standard states that communication to and consultation with the interested parties are important because they make judgments about risks based on their perceptions, which can vary in function of differences in their values, needs, assumptions and concerns.

Since points of view can have a significant impact on the decisions made, it is important for the perceptions of the stakeholders

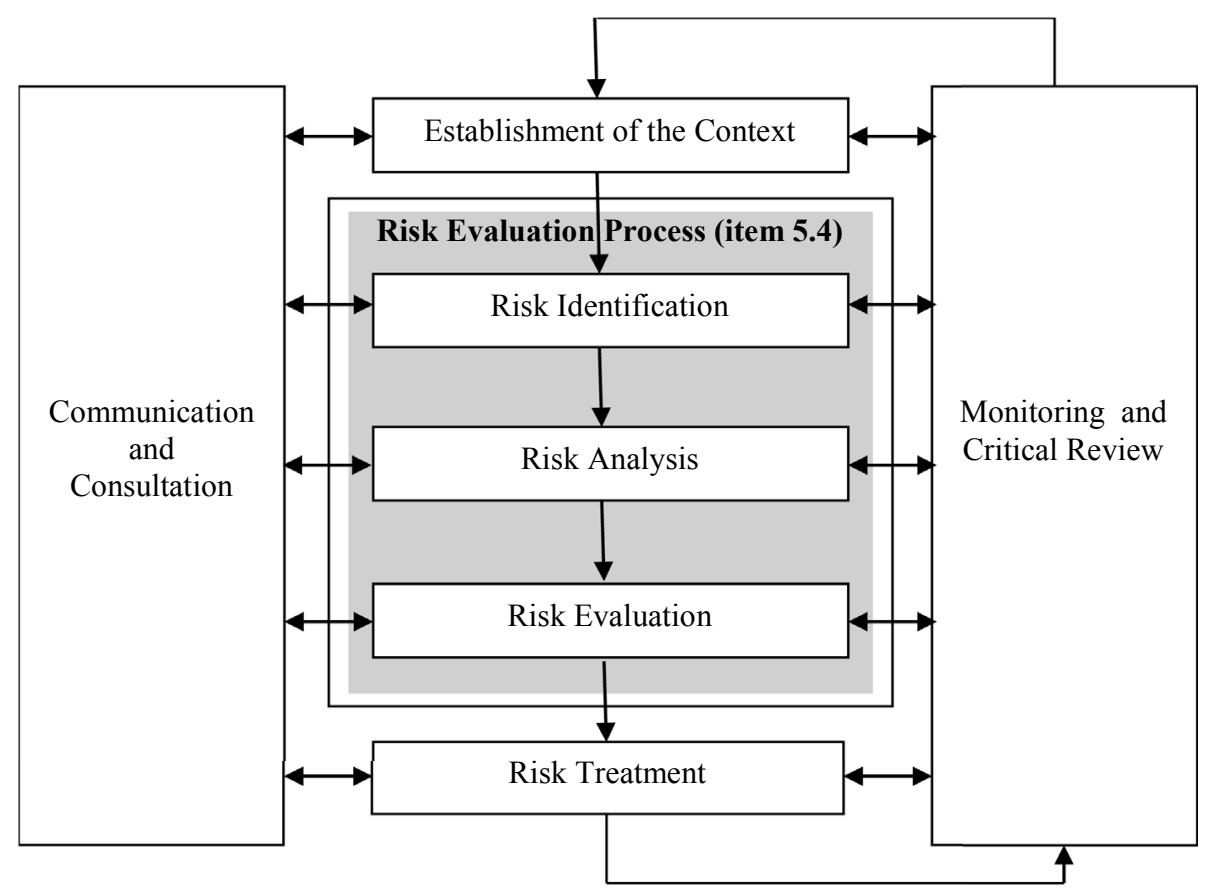

Fig. 3. Risk management process proposed by the ISO 31000:2009 standard. Source: ISO (2009a,b). 
to be identified, recorded and taken into consideration in the risk management process.

2. The step of establishing the context involves whether the firm articulates its objectives, defines the external and internal parameters that will be considered in managing risks and establishes the scope and risk criteria for the rest of the process.

Understanding the external context is important to assure that the objectives and concerns of the external stakeholders are considered in the development of the risk criteria. Understanding the internal context is relevant because this influences the way an organization will manage its risks.

Proper attention to these and other pertinent factors can help assure that the approach adopted to manage risks is suitable for the circumstances, the organization and the particular risks that affect the realization of its objectives.

3. Risk identification aims to generate a comprehensive list of risks from different sources, the events, their causes and potential consequences, and the areas affected.

4. Risk analysis aims to provide an understanding of risk to serve as the basis for making decisions on the best strategies and methods to deal with them. Risk analysis involves consideration of the causes and sources of risks, their negative consequences and the probability these consequences will occur.

Risk analysis can be carried out at various levels of detail, depending on the risk in question, the purpose of the analysis and the information available, given the resources at hand. Depending on the circumstances, the analysis can be quantitative or qualitative, or a combination of the two.

5. The purpose of risk evaluation is to provide more support for making decisions, based on the results of the risk analysis, by evaluating what risks need treatment and the priority of implementing that treatment.

Risk evaluation involves comparing the level of each risk, during the process of analysis, with the risk criteria established by considering the context. The priority or need for treatment of the risk is established based on this comparison.

6. Risk treatment entails the selection of one or more options to modify the risks and the implementation of these options, through a cyclical process that analyzes the treatments previously applied, residual risk levels, implementation of a new treatment for intolerable residual risks and evaluation of the efficacy of the treatment proposed.

The risk treatment options can include the following aspects: a) action to avoid the risk, either by not starting or discontinuing the activity that gives rise to the risk; b) accepting or even increasing the risk in an attempt to take advantage of an opportunity; c) removal of the source of the risk; d) alteration of its probability; e) alteration of the consequences; f) sharing the risk with one or more other parties (including through contractual arrangements or financing); and g) retaining the risk, through well-informed and well-reasoned decisions.

7. Monitoring and critical review should be planned as part of the risk management process, to clearly define responsibilities among those involved, covering all aspects of the risk management process, for the purpose of: a) assuring that the controls are effective and efficient in design and operation; b) obtaining additional information to improve the risk evaluation process; c) analyzing events (including "quasi-incidents"), changes, trends, successes, failures (and learning from them); d) detecting changes in the external and internal context, including alterations in the risk criteria and the risks themselves, which can require revision of the treatments of the risks and their priorities; and e) identifying emerging risks.

The ISO 31000 standard was developed for the purpose of providing the principles and guidelines for managing any form of risk in a systematic, transparent and reliable manner, within any scope and context. It can be applied to an entire organization, in its various areas and levels, at any moment, as well as to specific functions, activities and projects (ISO, 2009a,b).

\subsection{Research about ISO 31000 standard and indications of its possible use for SCRM}

Here we briefly touch on some of the studies that have applied or investigated ISO 31000 standard as a systematic procedure for risk management in particular settings. Everett (2011) presents ISO 31000 standard in managing information security risks, showing how organizations can benefit from that standard for this purpose.

Neves et al. (2015), investigating the risks of oil spills (oil spill risk assessment, or OSRA), develop a uniform method based on the ISO 31000 standard to manage those risks. According to the authors, the standard is general and recognized as effective, and can be adapted for a range of situations.

Ibanez et al. (2016) describe a system developed based on the standard, targeted at preventive conservation of architectural heritage. This system establishes a process to analyze and evaluate the vulnerability and main risks to buildings, according to their specific functionality.

Lalonde and Boiral (2012) identify some of the "pitfalls" that users of ISO 31000 standard can fall into due to misconceptions in interpreting and implementing it. They do not question the process utilized by the standard or its recommendations. On the contrary, they recognize that the generic character of the standard can contribute to a better identification and management of a variety of risks, including threats to the environment, public health, food safety and supply chain interruption. They stress that the methodological and structured approach of the ISO 31000 standard contributes to a systematic procedure for organizations to manage their risks.

\subsection{Multiple criteria decision analysis}

The ISO 31010 standard lists more than 30 tools and techniques for risk assessment: from Brainstorming to Multi-Criteria Decision Analysis (MCDA). MCDA is a discipline that helps decision-makers to make decisions when several conflicting criteria need to be evaluated (Ishizaka et al., 2012).

Analytic Hierarchy Process (AHP) is the most applied MCDA method (Wallenius et al., 2008). The many cases of success in AHP implementation evidence the property of this MCDA method to real problems (Salgado et al., 2012; Santos et al., 2015; Tramarico et al., 2017).

AHP is an MCDA method for synthesising priorities, structurally represented with a hierarchy (Saaty and Shih, 2009). Fig. 4 presents a hierarchical structure composed of three levels: objective, criteria and alternatives. In practice, an AHP application may require more levels, for instance, with the inclusion of subcriteria.

In AHP application, priorities of the alternatives are obtained with judgments provided by experts. These judgments composed the pairwise comparisons matrix, $\mathbf{A}$. The priorities are obtained 


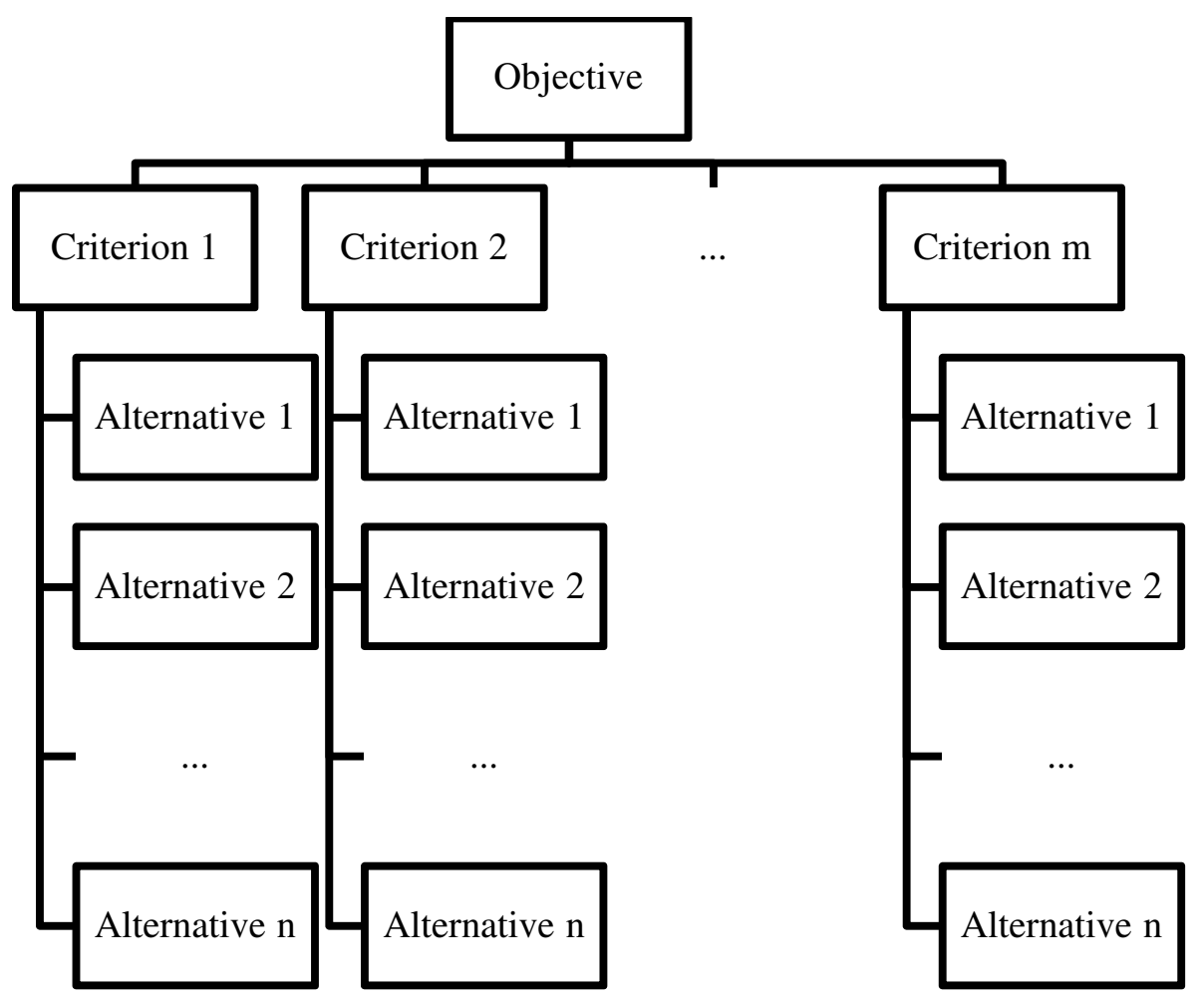

Fig. 4. Three-level multi-criteria hierarchy.

Source: Authors (2016)

with the comparison matrix's right eigen vector, w, as in Equation (1), where $\lambda_{\max }$ is the maximum eigenvalue:

$A w=\lambda_{\max } w$

The judgments inserted in $\mathbf{A}$ are often based in the Fundamental Scale (Saaty et al., 2009), a linear 1 to 9 scale. For a set of $n$ elements in a matrix, one needs $n(n-1) / 2$ judgments, because there are $n 1$ 's on the diagonal for comparing elements with themselves and of the remaining judgments, half are reciprocals. In some problems, one may elicit only the minimum of $n-1$ judments (Saaty, 1994).

The local priorities of the alternatives are obtained normalizing the eigenvector. There are two main modes of synthesis: the normal synthesis (the priorities sum 100\%) and the ideal synthesis (the best alternative for each criterion receives $100 \%$ priority, and the other receive their respective percentage). The main advantage of the ideal synthesis is that this mode avoids the ranking reversal, a possible situation with many MCDA methods, including AHP. With the ideal synthesis ranking is always preserved (Saaty et al., 2009).

AHP can be useful to prioritize risk assessment tools, and in this work, as presented in Section 5.2, AHP will be applied with this proposal, adopting the minimum of judgments and ideal synthesis.

\section{Material and methods}

The methodology used to carry out this research is two-fold:

- Systematic literature review (SLR) for ISO 31000 adoption purposes, adapted with the proposals of Tranfield et al. (2003), Thorpe et al. (2005), Seuring and Muller (2008), Jurado and Fuentes (2013) and Bouzon et al. (2014).

- A modeling using AHP to identify tools to applied in a SCRM procedure.

\subsection{Systematic literature review}

Webster and Watson (2002) define bibliographical research as that which is developed based on previously published material, having the main advantage of enabling the development of advances on topics where research is already consolidated. According to Meredith (1993), that method provides a significant improvement in the ability of researchers to construct valid theories in management of operations. This type of study naturally leads to synthesis of previous research presenting ideas that have been tested and validated.

According to Colicchia and Strozzi (2012), a study that uses information from several previous studies and really adds new knowledge and increases the visibility of the subject matter makes an important contribution to investigative progress. Other advantages of literature reviews are to supply a historical perspective and to consolidate the efforts of previous researchers in a determined area of knowledge (Mentzer and Kahn, 1995).

We carried out this Systematic Literature Review (SLR) in five steps, as described in Fig. 5.

We found 543 articles about SCRM in the first step: Scopus 220; WOS - 139; Ingenta - 66; Emerald - 63; and Science Direct $55)$. Although, we realized the existence of intersections (overlaps) between the databases in some cases, i.e., a single article was present in more than one base, as depicted in Fig. 6. Most of the articles about SCRM contained in the Science Direct, Ingenta Connect and Emerald Insight bases are also present in the Web of Science and Scopus bases. Besides this, the figure reveals an intersection of 107 articles between the two largest bases (Scopus and Web of Science).

Upon expunging the redundancies, 252 articles advanced to the second step. Out of them, articles containing the expressions listed in the third step of Fig. 5 (a total of 91 articles) were separated for 


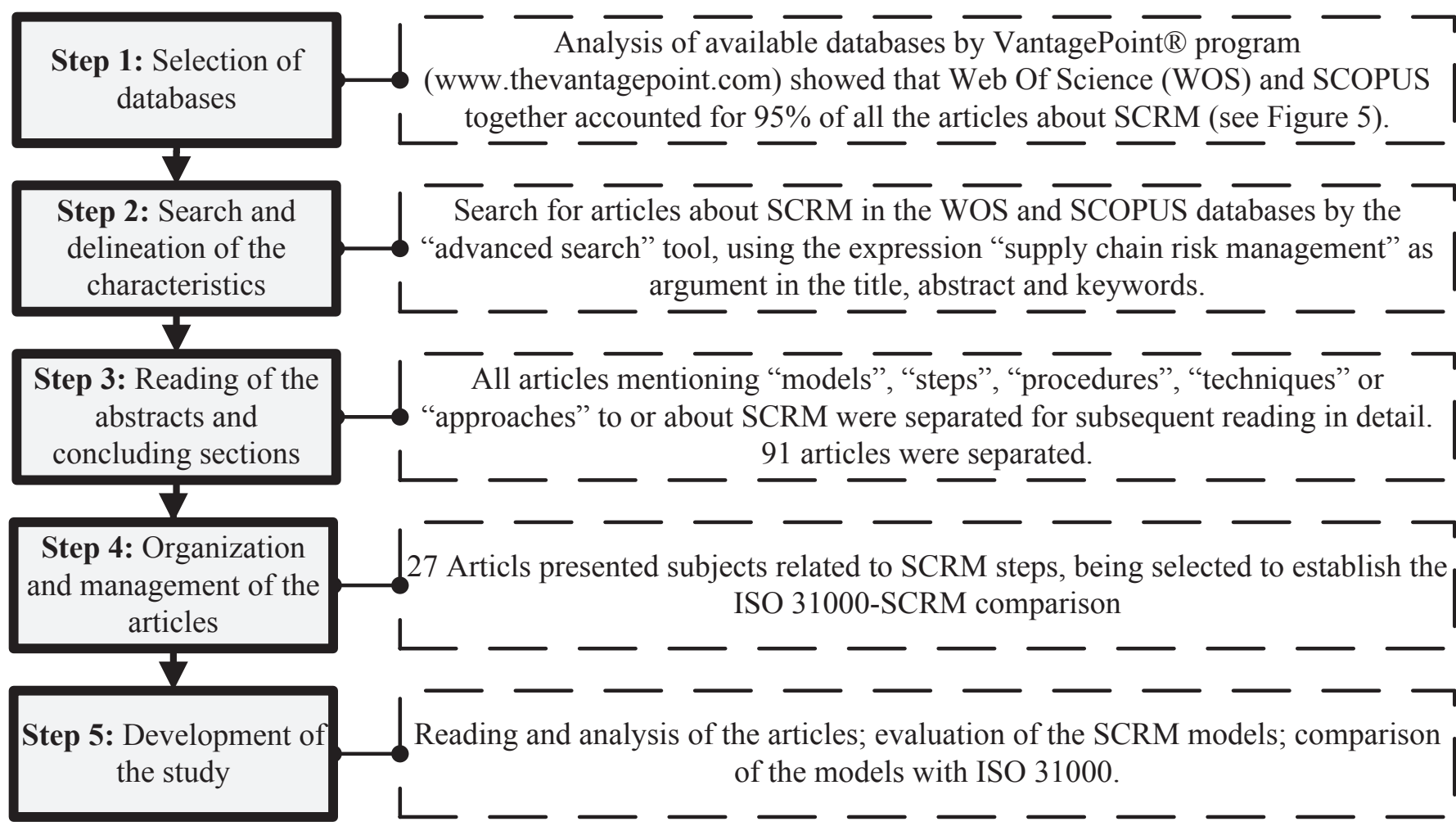

Fig. 5. Steps of the SLR.

Source: Authors (2016)

subsequent detailed reading. Just 27 of them presented subjects related to SCRM steps, being therefore, selected to establish the ISO 31000-SCRM comparison.

We adopted this method because we believe it is the most appropriate to attain the objectives of this study, since this method involves analyzing various positions regarding a research problem, in this case comparative mapping of various SCRM models according to the framework of the ISO 31000 standard.

\subsection{Analytic hierarchy process applied to SCRM}

In this section, we proposed the AHP to prioritize the tools to risk assessment listed in ISO 31010:2009, and we present, to illustrate this procedure, such application to the automotive supply chain.

Fig. 7 presents part of the hierarchical structure composed of three levels: objective, criteria and alternatives. As our objective is to identify highest priority tools, just the tools listed in ISO

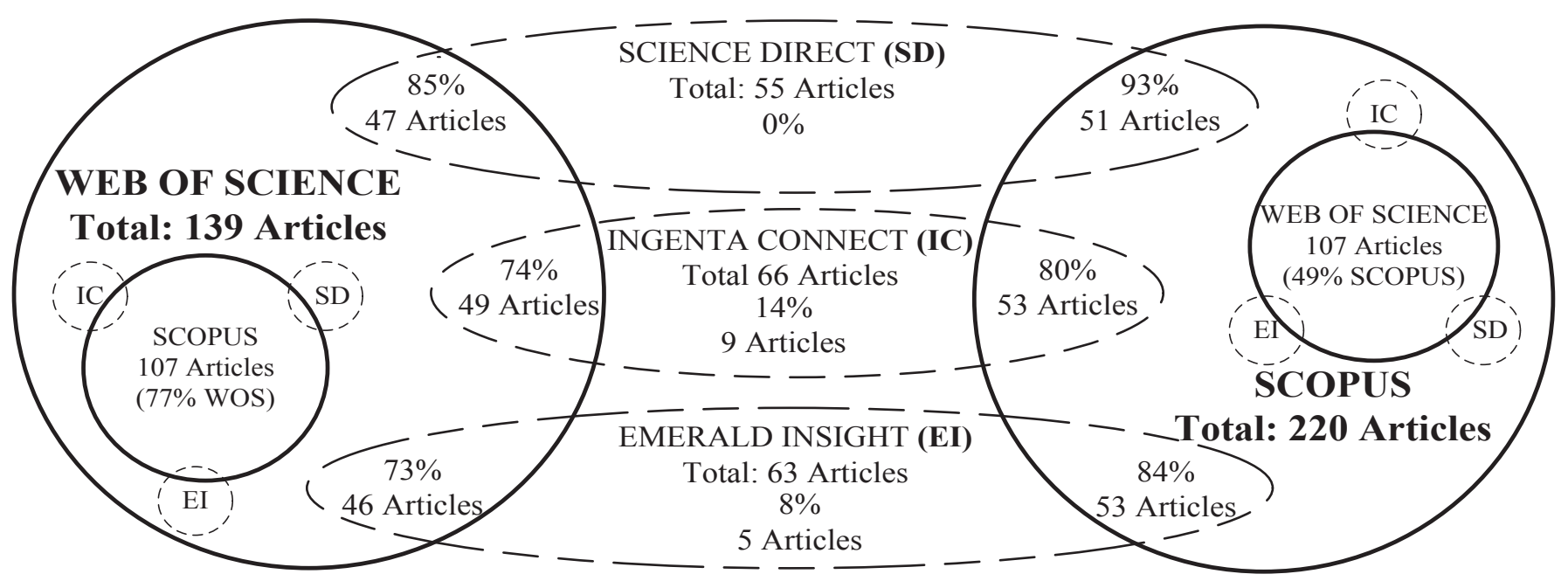

Fig. 6. Intersections of databases for publications on SCRM in the period from 2004 to 2015. Source: Authors (2016) 


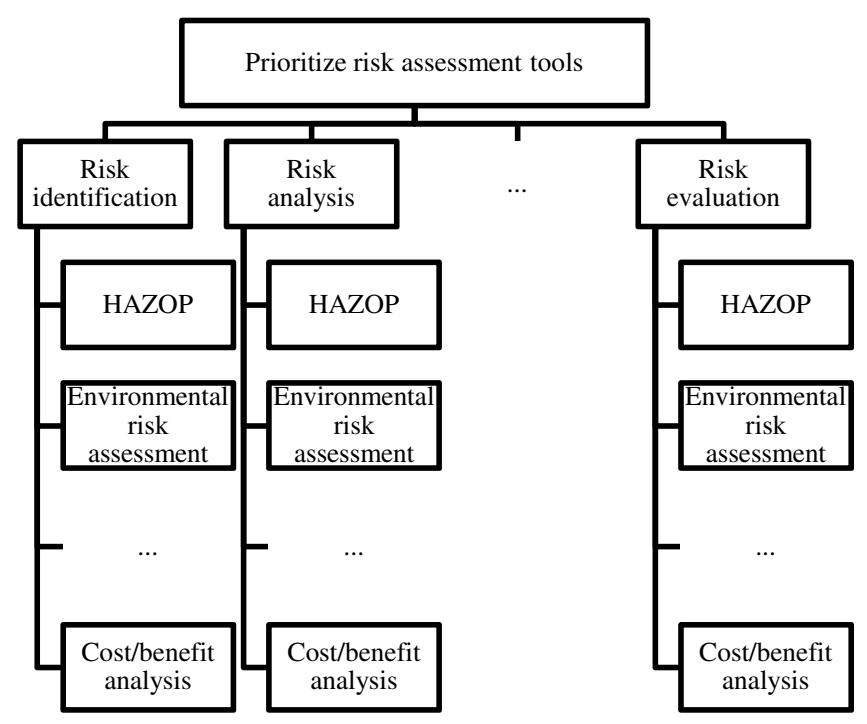

Fig. 7. Hierarchy model to prioritize risk assessment tools. Source: Authors (2016)

31010:2009 as strongly applicable (SA) and applicable (A) were selected to compose this step (a total of 13 tools).

The 13 risk assessment tools in the lowest level (alternatives) are: Hazard and operability study (HAZOP), Environmental risk assessment, Structured What If Technique (SWIFT), Scenario analysis, Business impact analysis, Failure mode and effects analysis (FMEA), Cause and consequence analysis, Human reliability analysis (HRA), Reliability centred maintenance, FN curve, Risk indices, Consequence/probability matrix, and Cost/benefit analysis.

Even then, being more than nine alternatives in the lowest level of the hierarchy, fulfillment of a complete pairwise matrices would be exhaustive for consulted experts. Also, $n>9$ matrices usualy lead to inconsistent judgments. So we decided to ask only the minimum 11 judgments for each criterion.

In regards to the interview with the specialists of a specific industrial segment, i.e., automotive industry, it is justified (ISO, 2009a,b) by:

- Inputs to the risk management process are based on many information sources, such as historical data, experiences, feedback from stakeholders, observations, forecasts, and expert opinions;

- Risk management is discretionary, tailor made, aligned with the internal and external context of the organization and with the risk profile;

- Risk management considers human and cultural factors.

Questionnaires intended to collect specialists perception about which tools mentioned in ISO 31010 are better suited for the identification, analysis and evaluation of risks, were applied to five professionals from different companys of a Brazilian automotive supply chain, acknowledged for their expertise in the area. Chart 1 presents the experts data, all of them have master degree (MBA or MSc) in Industrial Engineering.

\section{Systematic review of the literature on the steps of SCRM}

In this section we examine the existing knowledge on SCRM, based on the literature summarized below. Juttner et al. (2003) pointed out that events like the so-called "millennium bug", spikes in fuel prices, hoof and mouth disease in the United Kingdom and terrorist attacks in the United States reveal the vulnerability of modern supply chains. They reviewed the existing literature on supply chain vulnerability and risk management and compared the findings with the perceptions of managers of various industrial, retail and logistics firms, collected through interviews.

Aiming to establish an agenda for better understanding and future studies, they proposed four basic constructs: supply chain risk sources; risk consequences; risk drivers (e.g., globalization, the trend for outsourcing, etc.); and mitigating strategies, as shown in Fig. 8.

Gaonkar and Viswanadham (2007) also proposed these same four basic constructs for managing supply chain risks. Cases of SC vulnerability were also noted by Norrman and Jansson (2004): flooding of the Daimler-Chrysler factory, fire at the factory of a key supplier of Toyota, sudden drop in demand of Cisco and failures in planning for future demand by Nike were some of the examples mentioned by the authors. They also presented the structure and processes implemented by Ericsson after a fire at the plant of one of its suppliers, which caused severe impacts on the company. The model used by that company is based on processes of risk identification; risk evaluation; risk treatment; and risk monitoring, with treatment of incidents and planning for contingencies as parallel actions.

Kleindorfer and Saad (2005) also described various examples of supply chain ruptures, such as the earthquake in Taiwan in 1999, the terrorist attack on the Twin Towers in 2001 and the blackout in the northeastern United States in 2003. The model proposed by the authors to manage the risk of disruptions and assure greater security of global supply networks includes the establishment of voluntary standards for security; classification of assets and processes in terms of vulnerability; ranking of efforts; and iteration for continuous improvement.

Harland et al. (2003) also pointed to the increasing complexity of products and services and rising outsourcing and globalization as factors making supply chains more complex and vulnerable, aspects also mentioned by Singhal et al. (2011). The latter authors proposed a tool to identify, evaluate and manage risks and tested it in four cases in the electronics industry. That tool, depicted in Fig. 9, is divided into six blocks: supply network mapping (structure of the actors, metrics and responsibilities); identification of risks and their location (type and potential losses); risk evaluation (probability of occurrence, life cycle stage, exposure, possible triggers and potential losses); risk management (developing risk positions and scenarios); collaborative strategy making to face SC risks; and strategy

Chart 1

Consulted Brazilian automotive supply chain experts.

\begin{tabular}{lll}
\hline Expert & Company & Position \\
\hline E1 & French automobile manufacturers & Logistics supervisor \\
E2 & French tire company & O\&M manager \\
E3 & German automobile manufacturers & Quality manager \\
E4 & U.S. automobile manufacturer & Senior Product engineer \\
E5 & Japanese automobile manufacturer & 7-year \\
\hline
\end{tabular}

Source: Authors (2016) 


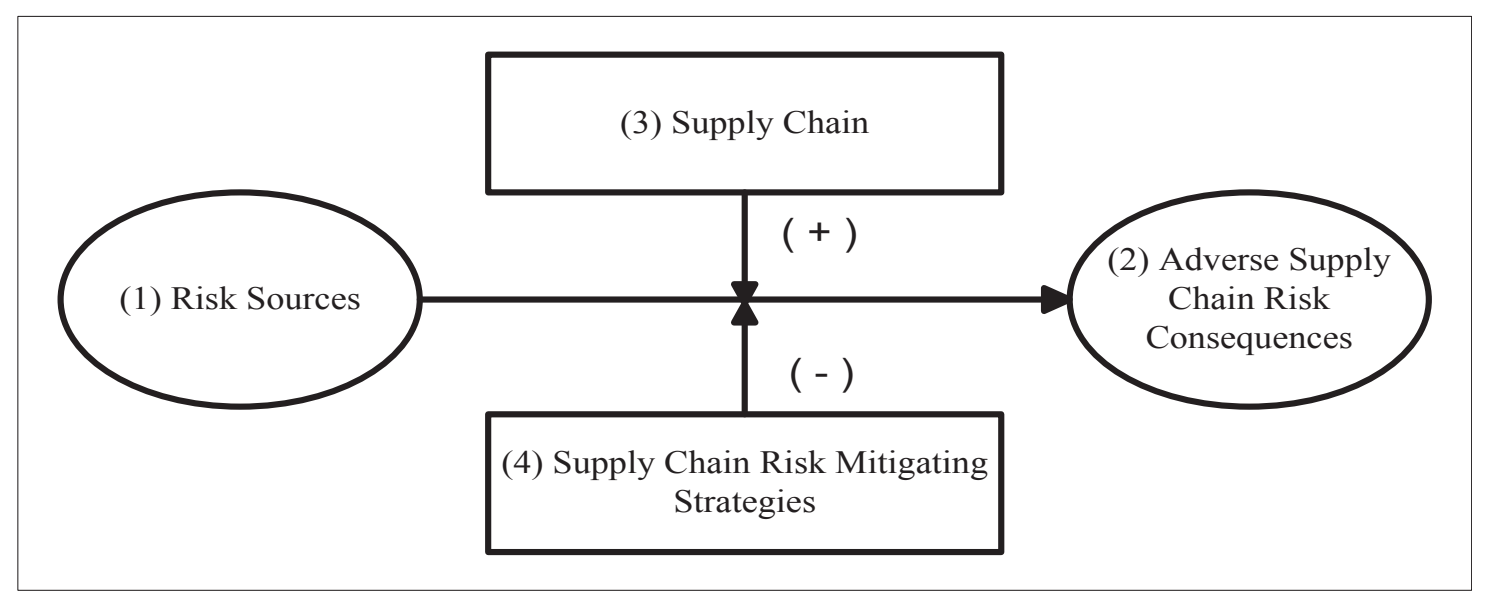

Fig. 8. Basic supply chain risk management model.

Source: Juttner et al. (2003)

\section{implementation.}

Also mentioning the complexity of supply chains, Hallikas et al. (2004), Faisal et al. (2006) and Tuncel and Alpan (2010) argued that a typical risk management process is composed of risk identification, risk evaluation; decision and implementation of risk management actions, and risk monitoring.

The model proposed by Ritchie and Brindley (2007) takes a different approach, proposing five components: context of risks and their drivers; factors influencing risk management (including time frames and portfolio); decision makers (perceptions, profile, attitudes and experiences); responses to risk management (acceptance, avoidance, mitigation and monitoring); and final performance (related to profile, strategic positioning and personnel), as shown Fig. 10.

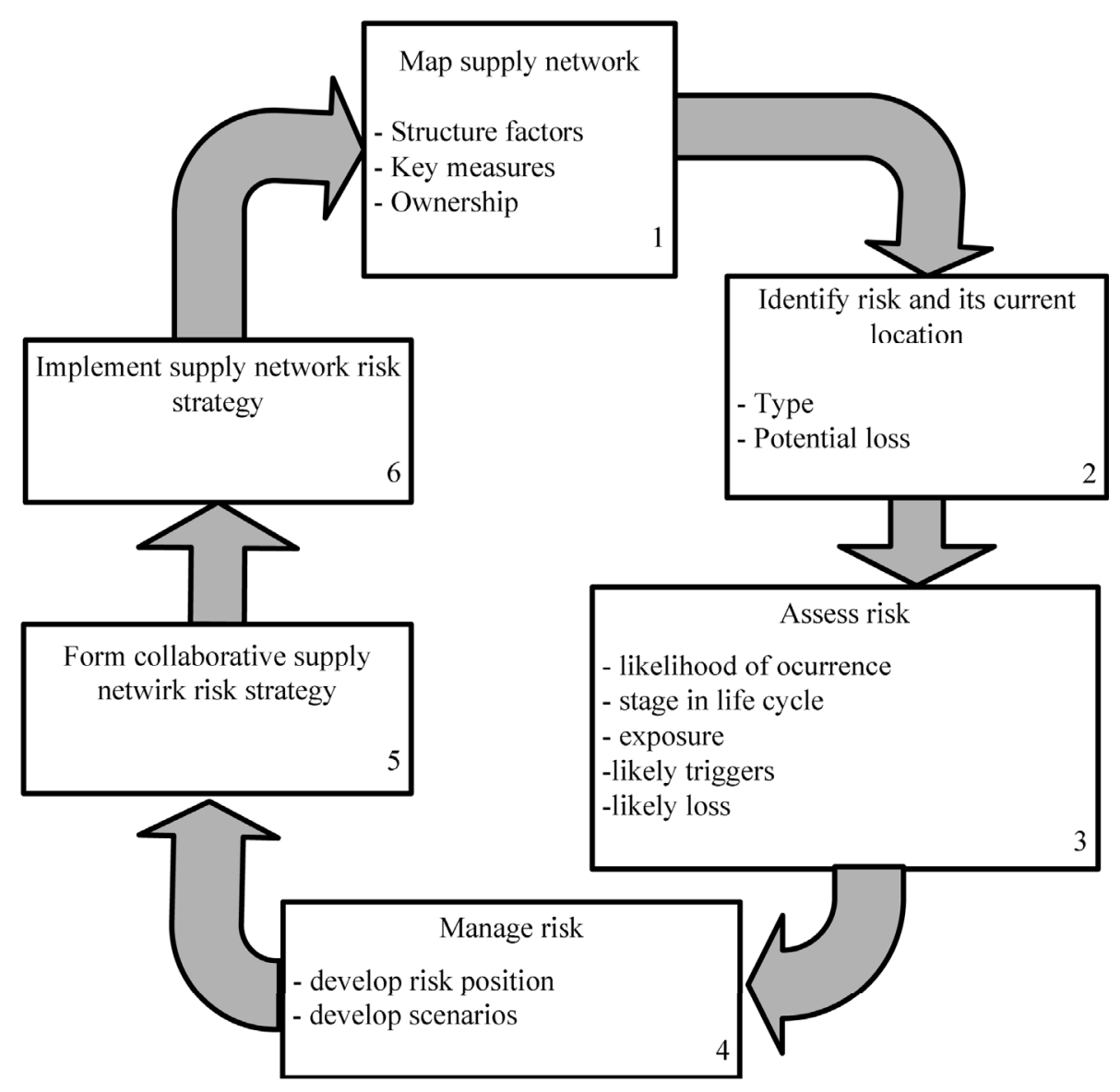

Fig. 9. Supply network risk management tool. 


\begin{tabular}{|c|c|c|c|c|}
\hline $\begin{array}{l}\text { Risk Context } \\
\text { and Drivers } \\
\text { Primary level } \\
\text { Secondary level }\end{array}$ & $\begin{array}{c}\text { Risk Management } \\
\text { Influencers } \\
\text { Rewards } \\
\text { Supply Chain Risk } \\
\text { Timescales } \\
\text { Portfolio }\end{array}$ & $\begin{array}{c}\text { Decision } \\
\text { Maker(s) } \\
\text { Perceptions } \\
\text { Risk Profile } \\
\text { Attitudes } \\
\text { Experiences }\end{array}$ & $\begin{array}{c}\text { Risk } \\
\text { Management } \\
\text { Responses } \\
\text { Risk Taking } \\
\text { Avoidance } \\
\text { Mitigation } \\
\text { Monitoring }\end{array}$ & $\begin{array}{c}\text { Performance } \\
\text { Outcomes } \\
\text { Profit-related } \\
\text { Strategic } \\
\text { Positioning } \\
\text { Personal }\end{array}$ \\
\hline
\end{tabular}

Fig. 10. SCRM structure.

Source: Ritchie and Brindley (2007)

In turn, Wu et al. (2006), focusing on the risks of inbound logistics, sought to identify risk factors, also through a literature review and interviews. They proposed a model to manage these risks composed of four components: classification of SC risks (internally controllable, partly internally controllable, internally uncontrollable, externally controllable, partly externally controllable, and externally uncontrollable); identification of risks in suppliers; calculation of risks by applying the analytic hierarchy planning (AHP) method (Saaty, 1994); and computer simulation (O'kane et al., 2000).

Kern et al. (2012) also analyzed inbound logistics and proposed a model to manage the associated risks, composed of risk identification; risk evaluation; risk mitigation; and performance in facing risks, also examining the impact of the ongoing improvement process on these constructs, as shown in Fig. 11.

Matook et al. (2009) focused on upstream risk management. They proposed a model composed of five components: identification of the risks in suppliers; evaluation of the risks in suppliers; reporting and decision regarding the risks posed by suppliers; responses for managing these risks; and measurement of the performance of suppliers in responding to risks.

Blome and Schoenherr (2011) also focused attention on suppliers, using multiple case studies in eight European enterprises to identify successful experiences and approaches, and developed a model for managing risks during financial crises. The proposed model contains the following steps for managing risks in supply chains and in the central company itself: risk identification; risk analysis; risk mitigation; and risk monitoring. This model is very similar to that put forward by Rangel et al. (2015), which indicated identification, analysis, management and monitoring of risks, followed by organizational and personal learning with transfer of knowledge.

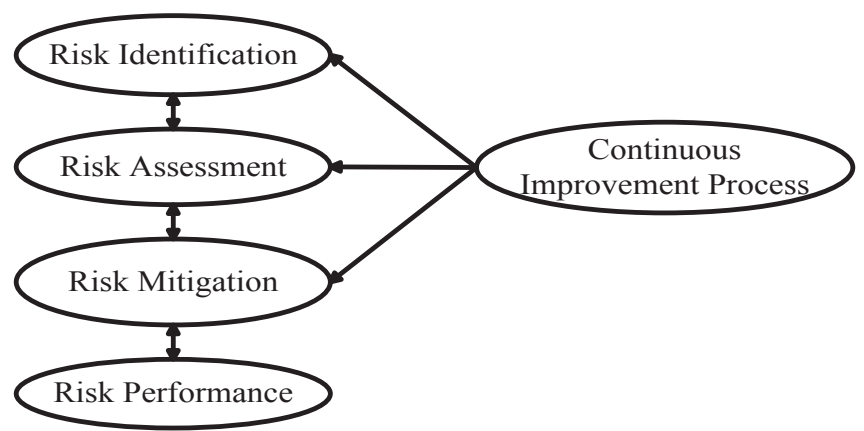

Fig. 11. SCRM conceptual model. Source: Kern et al. (2012)
The analysis of risk management at moments of economic downturns was also the focus of the study by Giannakis and Louis (2011), who presented a model of a multi-agent system to support decisions on management of ruptures and mitigation of risks in manufacturing supply chains. The risk management process is composed of four stages: risk identification; risk evaluation; decision and implementation of risk management actions; and optimization.

Manuj and Mentzer (2008), who unlike the authors of the previously mentioned articles, focused on global supply chains, indicated a process to manage and mitigate risks with this scope composed of five steps: risk identification (classified as supply, operations, demand and security); risk analysis and evaluation (analysis of decisions, case studies and support in perception); selection of appropriate risks to manage (i.e., the proposed strategy: avoid, postpone, speculate, limit, control, share/transfer and insure); implementation of strategies (having as facilitators management of complexity, organizational learning, information technology and performance indicators); and risk mitigation (preparing for unforeseen events), as indicated in Figs. 12 and 13.

Cohen and Kunreuther (2007), on the other hand, proposed a more detailed model SCRM, composed of: risk evaluation and analysis; risk modeling; formulation of risk management strategies; and evaluation of strategies, as can be seen in Fig. 14.

The literature review of Khan and Burnes (2007) identified that the majority of risk management approaches tend to be similar, involving three critical stages: risk identification (perception of hazards, identification of failures and recognition of adverse consequences); risk estimation (estimation of the probabilities of risks, description and quantification of risks); and risk evaluation (estimation of the significance of risks, judgment of their acceptability and comparison of risks with benefits), as depicted in Fig. 15.

Tummala and Schoenherr (2011) proposed a supply chain risk management process composed of three phases: identification, measurement and analysis of risks; evaluation of risks, preparation of contingency plans and mitigation of risks; and control and monitoring of risks, as seen in Fig. 16.

\section{Results and analysis}

\subsection{Systematic literature review}

In the analysis papers about SCRM, we realized that even though all analyzed paper define "Risk" on the approximately same way as it stated in ISO 31000 , each author establishes different steps to develop a SCRM process. Chart 2 below consolidates the phases and constructs proposed by the various authors who have studied the steps and procedures for SCRM. 


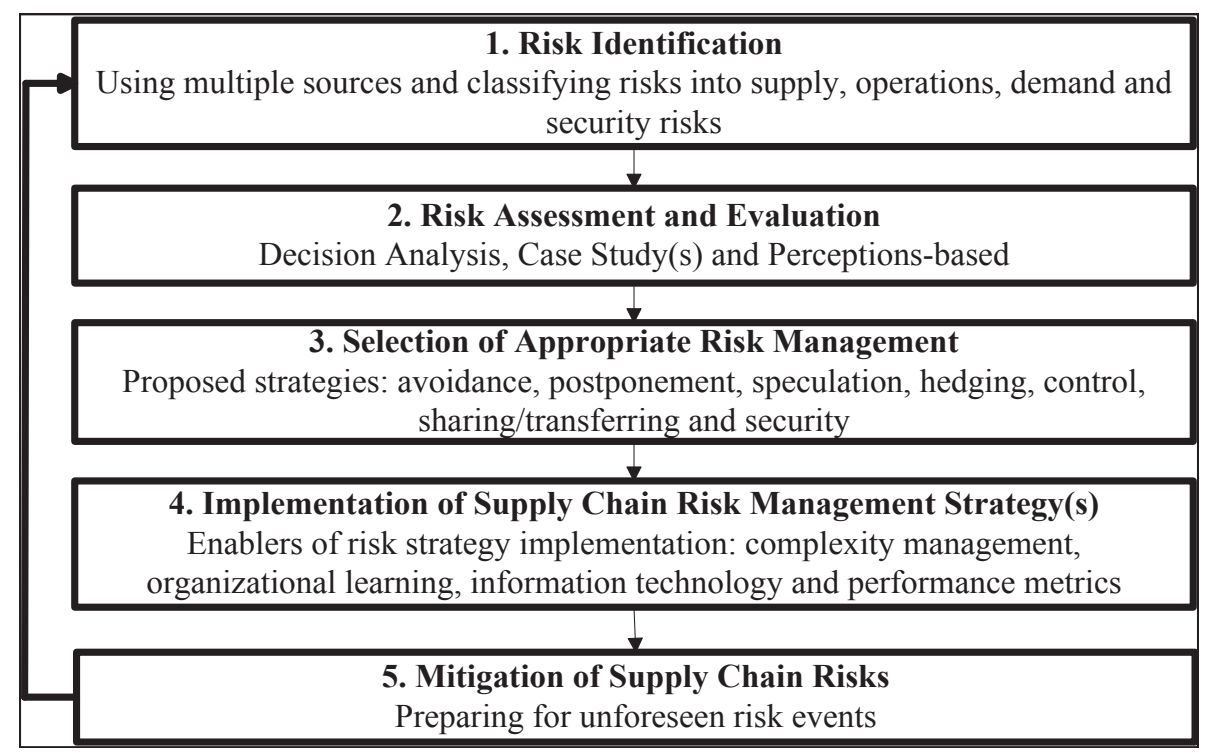

Fig. 12. A five-step SCRM process. Source: Manuj and Mentzer (2008)

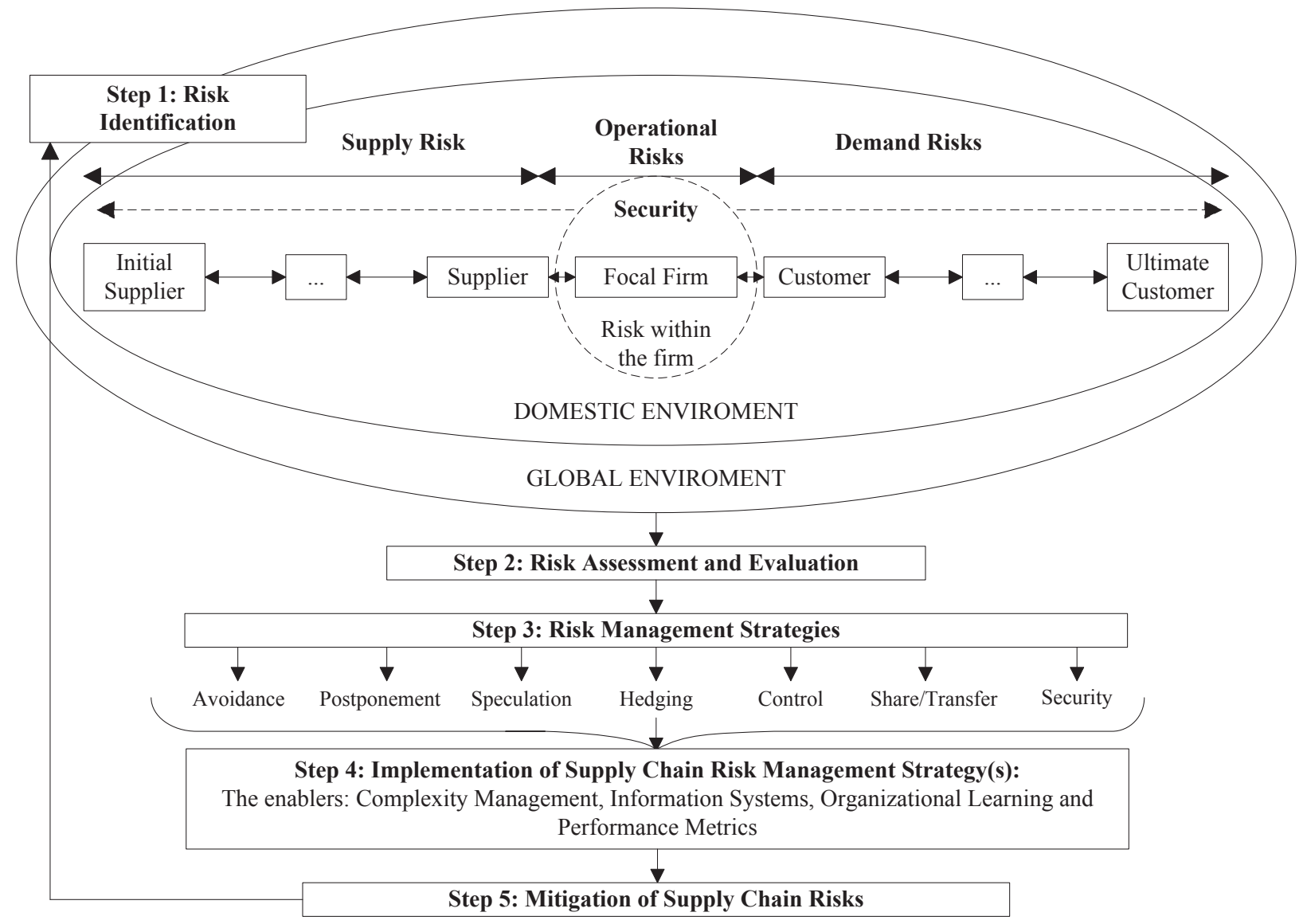

Fig. 13. SCRM structure.

Source: Manuj and Mentzer (2008)

A simple check of the steps of SCRM in Chart 2, disregarding different variations in the names given to each of these steps by the 27 researchers/groups, shows that: i) 92.59\% address the risk evaluation step; ii) $85.18 \%$ address the risk identification step; iii)
62.96\% address the risk mitigation step; iv) $33.33 \%$ address the risk monitoring step.

However, analysis of the works of the various authors during the systematic literature review (previous section) indicated that these 


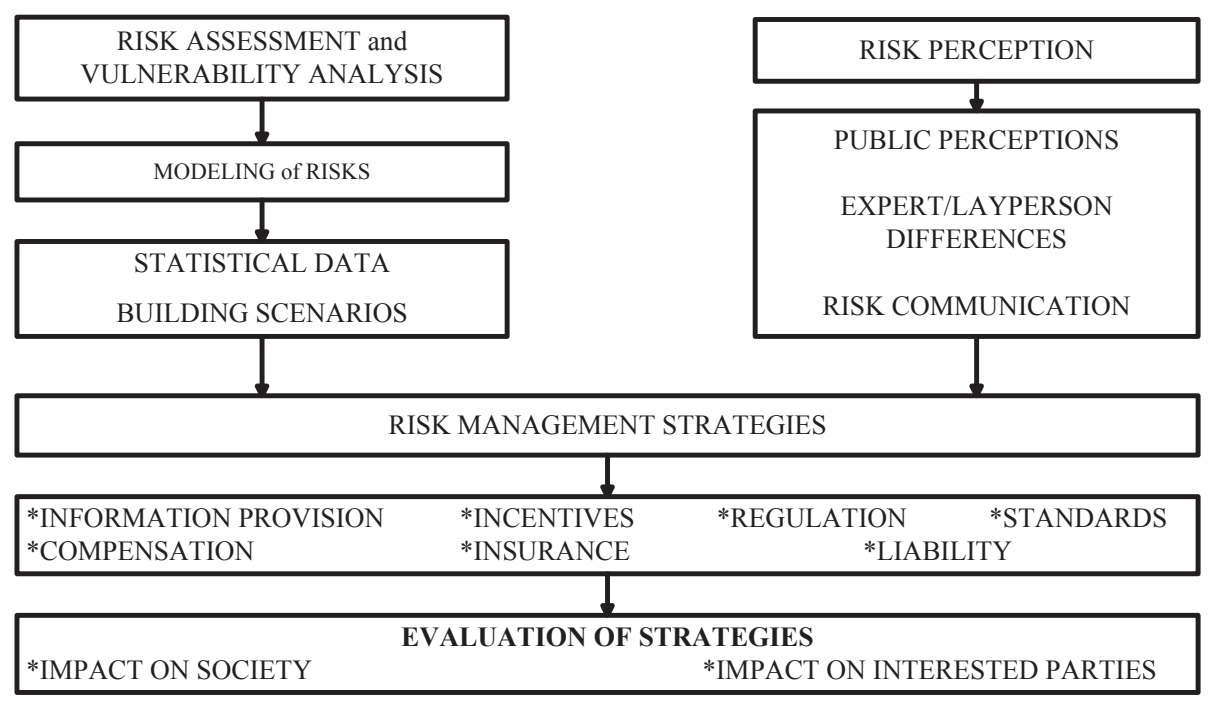

Fig. 14. Conceptual structure for risk analysis.

Source: Adapted from Cohen and Kunreuther (2007)

percentages are higher, due to the existence of similar (or even identical) steps in the SCRM processes that can be harmonized and/ or absorbed by the phases of the ISO 31000 standard. Therefore, to better understand the meaning attributed to each step, we carried out an analysis of correspondence with the standard. The results are summarized in Fig. 17.

Analysis of Fig. 17 reveals that:

- $96.30 \%$ of the articles address the risk identification step;

- $44.44 \%$ address the risk analysis step;

- $92,59 \%$ address the risk evaluation step;

- $100 \%$ address the risk treatment step;

- $66.67 \%$ address the risk monitoring step.

Although Jia and Rutherford (2010) advocate four basic steps for SCRM, not including the risk identification step in this construct (see Chart 2), they do define it as involving the identification of the potential sources of risks and the implementation of actions to avoid or restrict vulnerability of the supply chain. Therefore, Jia and Rutherford (2010) implicitly cover risk identification, as stated by ISO 31000 standard. Consequently, we can state that $100 \%$ of the 27 articles surveyed cover that step.

Furthermore, in several of the articles the authors consider risk evaluation and risk analysis to be a single step in SCRM. For this reason, only $44.44 \%$ of the articles studied address risk analysis. According to ISO (2009a,b), risk analysis involves consideration of the causes and sources of risks, their negative consequences, and the probability of occurrence of these consequences. In turn, risk evaluation has the purpose of weighting or ranking the risks that need treatment and the priority for implementing treatment.

The results also show that two-thirds of the articles include the risk monitoring step within the scope of SCRM. Even though onethird do not allude to this step, it is still extremely important, since the process of monitoring and critical review indicated by the ISO 31000 standard has the purpose of: i) assuring that the controls are effective and efficient in design and operation; ii) obtaining additional information to improve the risk evaluation process; iii) analyzing events, changes, trends, successes and failures, and learning from them; iv) detecting changes in the external and internal contexts, which can require revision of the risk treatments and their priorities; and v) identifying emerging risks.

Therefore, after analyzing the meaning of each step proposed in each article, and seeking correspondence of these steps with the ISO 31000 standard, we reached a systematic process consisting of five steps for SCRM, as presented in Fig. 18.

In closing, we note that in the literature some studies adopted the ISO 31000 standard as a procedure for performing SCRM, albeit

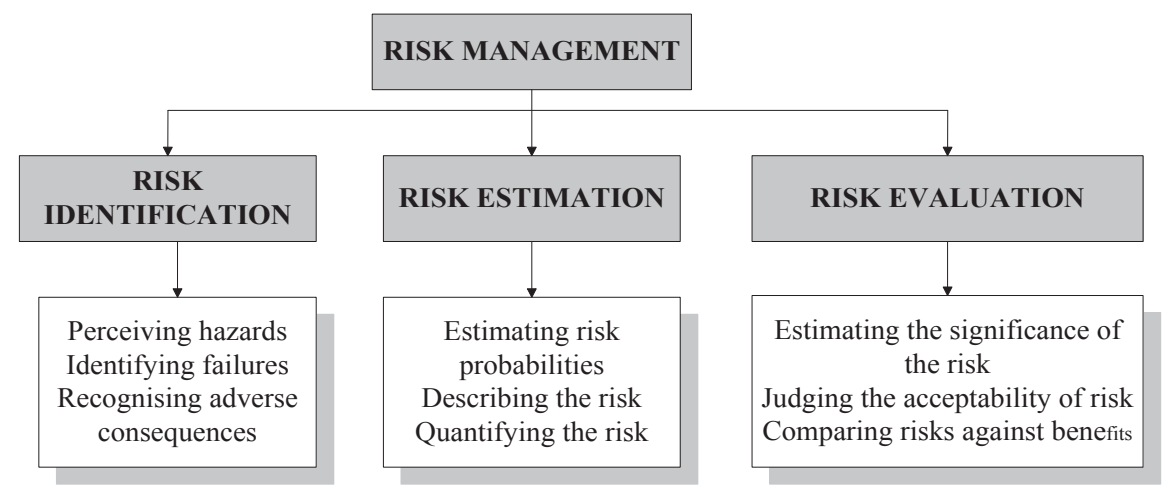

Fig. 15. The risk management process.

Source: White (1995) 


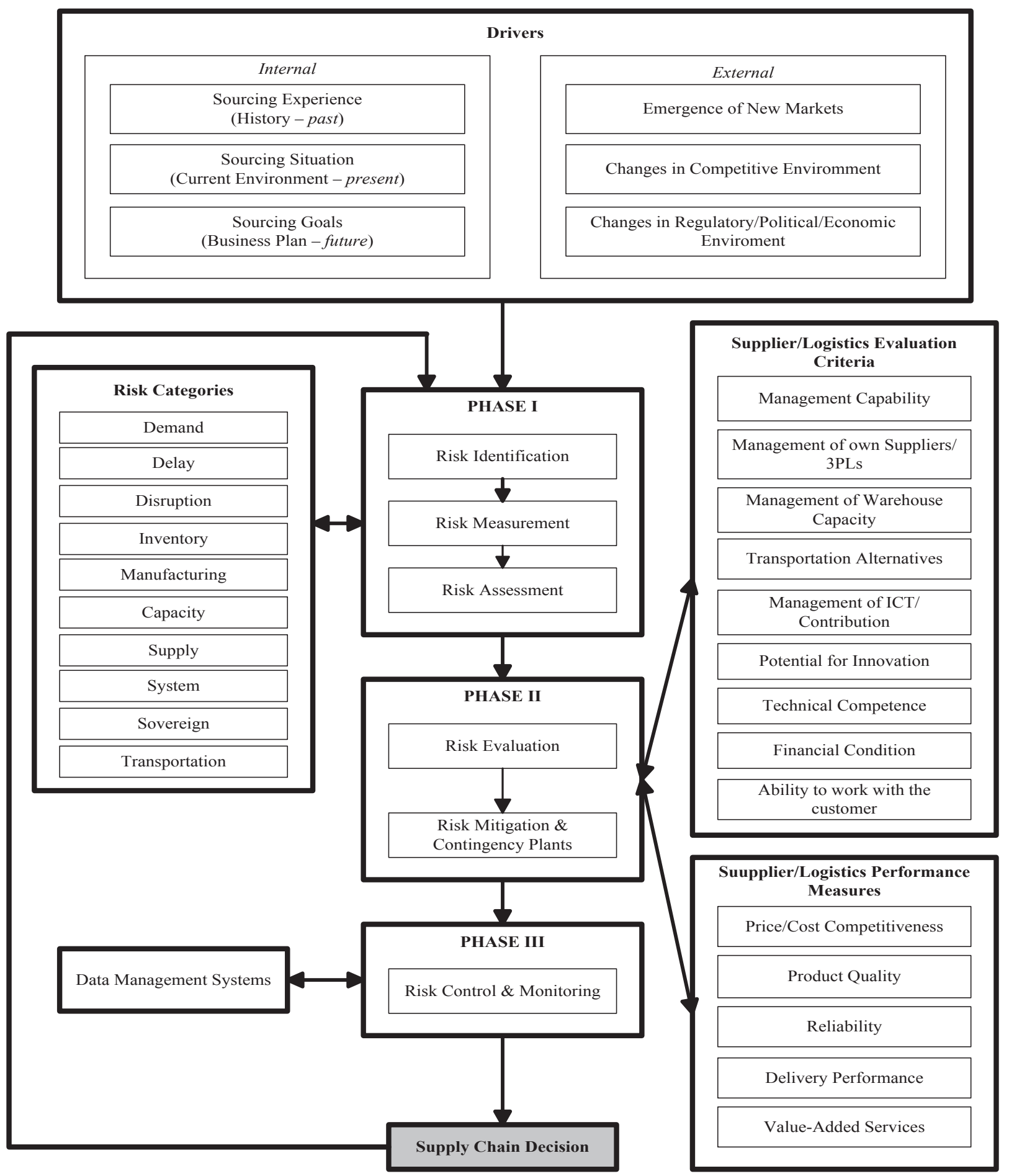

Fig. 16. Supply chain risk management process.

Source: Tummala and Schoenherr (2011)

implicitly. Rotaru et al. (2014), for example, use of the supply chain risk management process by the SCOR (Supply Chain Operations Reference Model), while Marija et al. (2015) also clearly suggest a SCRM model based on the recommendations of the ISO 31000 standard.

Notwithstanding the findings discussed above, it should be considered that problems in supply chains do not always present the same demands, and hence the same solution methods.
Lalonde and Boiral (2012), for instance, state that risk management will always be carried out with a significant degree of unpredictability and uncertainty, thus requiring care in its realization. Further according to them, this need for vigilance does not necessarily mean questioning the ISO 31000 standard or its main recommendations, but rather taking into consideration how it should be interpreted and implemented by organizations to fit specific situations. 
Chart 2

List of steps for SCRM in the view of various authors.

\begin{tabular}{|c|c|c|c|c|c|c|c|c|c|c|c|c|c|c|}
\hline \multirow{2}{*}{$\begin{array}{l}\text { Order } \\
\text { (codification } \\
\text { for Fig. 17) }\end{array}$} & \multirow{2}{*}{$\begin{array}{l}\text { Researchers on } \\
\text { SCRM }\end{array}$} & \multicolumn{13}{|c|}{ List of SCRM steps } \\
\hline & & $\begin{array}{l}\text { Analysis } \\
\text { of risks }\end{array}$ & $\begin{array}{l}\text { Identification } \\
\text { of risks }\end{array}$ & $\begin{array}{l}\text { Mitigation } \\
\text { of risks }\end{array}$ & $\begin{array}{l}\text { Proposal } \\
\text { of } \\
\text { strategies }\end{array}$ & $\begin{array}{l}\text { Monitoring } \\
\text { of risks }\end{array}$ & $\begin{array}{l}\text { Control } \\
\text { of risks }\end{array}$ & $\begin{array}{l}\text { Measurement of he } \\
\text { consequences of risks }\end{array}$ & $\begin{array}{l}\text { Identification of } \\
\text { s the source of risks }\end{array}$ & $\begin{array}{l}\text { Measurement } \\
\text { of results }\end{array}$ & $\begin{array}{l}\text { Measurement } \\
\text { of risks }\end{array}$ & $\begin{array}{l}\text { Identification } \\
\text { of risk factors }\end{array}$ & $\begin{array}{l}\text { Ongoing } \\
\text { improvement } \\
\text { process }\end{array}$ & $\begin{array}{l}\text { Mapping } \\
\text { of } \\
\text { indicators }\end{array}$ \\
\hline 1 & $\begin{array}{l}\text { Juttner et al. } \\
(2003)\end{array}$ & $\mathrm{X}$ & & $\mathrm{x}$ & & $\mathrm{X}$ & & & $\mathrm{X}$ & & & & & \\
\hline 2 & $\begin{array}{l}\text { Harland et al. } \\
(2003)\end{array}$ & $\mathrm{X}$ & $\mathrm{x}$ & & $\mathrm{X}$ & & & $\mathrm{X}$ & & & & & & $\mathrm{x}$ \\
\hline 3 & $\begin{array}{l}\text { Hallikas et al. } \\
(2004)\end{array}$ & $\mathrm{X}$ & $\mathrm{x}$ & $\mathrm{x}$ & & $\mathrm{X}$ & $\mathrm{X}$ & & & & & & & \\
\hline 4 & $\begin{array}{l}\text { Norrman and } \\
\text { Jansson (2004) }\end{array}$ & $\mathrm{X}$ & $\mathrm{x}$ & & $\mathrm{X}$ & $\mathrm{X}$ & & & & & & & & \\
\hline 5 & $\begin{array}{l}\text { Kleindorfer and } \\
\text { Saad (2005) }\end{array}$ & $\mathrm{X}$ & & $\mathrm{x}$ & $\mathrm{X}$ & & & & $\mathrm{X}$ & & & & & \\
\hline 6 & $\begin{array}{l}\text { Zsidisin et al. } \\
\text { (2005) }\end{array}$ & $\mathrm{X}$ & $\mathrm{x}$ & & $\mathrm{X}$ & & $\mathrm{X}$ & $\mathrm{X}$ & & & & & & \\
\hline 7 & Wu et al. (2006) & $\mathrm{x}$ & $\mathrm{x}$ & $\mathrm{x}$ & & & & & & & $\mathrm{x}$ & & & \\
\hline 8 & Faisal et al. (2006) & $x$ & $\mathrm{x}$ & $\mathrm{x}$ & & $\mathrm{x}$ & & & & & & & & \\
\hline 9 & $\begin{array}{l}\text { Khan and Burnes } \\
\text { (2007) }\end{array}$ & & $\mathrm{x}$ & & $\mathrm{X}$ & & & $\mathrm{X}$ & & & & & & \\
\hline 10 & $\begin{array}{l}\text { Ritchie and } \\
\text { Brindley (2007) }\end{array}$ & & $\mathrm{x}$ & & $\mathrm{X}$ & $\mathrm{X}$ & $\mathrm{X}$ & & $\mathrm{X}$ & $\mathrm{x}$ & & $\mathrm{X}$ & & \\
\hline 11 & $\begin{array}{l}\text { Gaonkar and } \\
\text { Viswanadham } \\
\text { (2007) }\end{array}$ & $\mathrm{X}$ & & & $\mathrm{x}$ & & & $\mathrm{x}$ & $\mathrm{x}$ & & & $\mathrm{x}$ & & \\
\hline 12 & $\begin{array}{l}\text { Cohen and } \\
\text { Kunreuther } \\
\text { (2007) }\end{array}$ & $\mathrm{X}$ & $\mathrm{x}$ & $\mathrm{x}$ & $\mathrm{X}$ & & & $\mathrm{X}$ & & $\mathrm{x}$ & & & & \\
\hline 13 & $\begin{array}{l}\text { Manuj and } \\
\text { Mentzer (2008) }\end{array}$ & $\mathrm{x}$ & $\mathrm{x}$ & $\mathrm{x}$ & $\mathrm{x}$ & & & $\mathrm{x}$ & & & & & & \\
\hline 14 & $\begin{array}{l}\text { Matook et al. } \\
\text { (2009) }\end{array}$ & $\mathrm{X}$ & $\mathrm{x}$ & & $\mathrm{X}$ & & $\mathrm{X}$ & & & $\mathrm{x}$ & $\mathrm{x}$ & & & \\
\hline 15 & $\begin{array}{l}\text { Oehmen et al. } \\
\text { (2009) }\end{array}$ & $\mathrm{X}$ & $\mathrm{x}$ & $\mathrm{x}$ & & & & & & & & & & \\
\hline 16 & $\begin{array}{l}\text { Tuncel and Alpan } \\
\text { (2010) }\end{array}$ & $x$ & $\mathrm{x}$ & & $\mathrm{X}$ & $\mathrm{X}$ & & & & & & & & \\
\hline 17 & $\begin{array}{l}\text { Jia and } \\
\text { Rutherford } \\
\text { (2010) }\end{array}$ & $\mathrm{x}$ & & $\mathrm{x}$ & & & $\mathrm{x}$ & $\mathrm{x}$ & & & & & & \\
\hline 18 & Pfohl et al. (2010) & $x$ & $\mathrm{x}$ & $\mathrm{x}$ & & & $\mathrm{x}$ & & & & & & & \\
\hline 19 & $\begin{array}{l}\text { Blome and } \\
\text { Schoenherr } \\
\text { (2011) }\end{array}$ & $\mathrm{X}$ & $\mathrm{x}$ & $\mathrm{x}$ & & & $\mathrm{X}$ & & & & & & & \\
\hline 20 & Guo (2011) & $\mathrm{x}$ & $\mathrm{x}$ & & $\mathrm{x}$ & $\mathrm{x}$ & & & & & & & & \\
\hline 21 & $\begin{array}{l}\text { Singhal et al. } \\
\text { (2011) }\end{array}$ & $\mathrm{X}$ & $\mathrm{x}$ & $\mathrm{x}$ & & & & & & & & & & \\
\hline 22 & $\begin{array}{l}\text { Giannakis and } \\
\text { Louis (2011) }\end{array}$ & $\mathrm{x}$ & $\mathrm{x}$ & $\mathrm{x}$ & $\mathrm{x}$ & & $\mathrm{x}$ & & & & & & & \\
\hline 23 & $\begin{array}{l}\text { Tummala and } \\
\text { Schoenherr } \\
\text { (2011) }\end{array}$ & $\mathrm{x}$ & $\mathrm{x}$ & $\mathrm{x}$ & & $\mathrm{x}$ & $\mathrm{x}$ & & & & $\mathrm{x}$ & & & \\
\hline 24 & $\begin{array}{l}\text { Lavastre et al. } \\
\text { (2012) }\end{array}$ & $\mathrm{x}$ & $\mathrm{x}$ & $\mathrm{x}$ & $\mathrm{X}$ & & & $\mathrm{X}$ & $\mathrm{X}$ & & & & & \\
\hline 25 & Kern et al. (2012) & $x$ & $\mathrm{x}$ & $\mathrm{x}$ & & & & & & $\mathrm{x}$ & & & $\mathrm{x}$ & \\
\hline 26 & $\begin{array}{l}\text { Elleuch et al. } \\
\text { (2014) }\end{array}$ & $\mathrm{x}$ & $\mathrm{x}$ & $\mathrm{x}$ & $\mathrm{X}$ & & & & & $\mathrm{x}$ & & & & \\
\hline 27 & $\begin{array}{l}\text { Rangel et al. } \\
\text { (2015) }\end{array}$ & $\mathrm{x}$ & $\mathrm{x}$ & & $\mathrm{x}$ & $\mathrm{x}$ & & & & & & & & \\
\hline \multicolumn{2}{|c|}{ TOTAL PER STEP } & 25 & 23 & 17 & 16 & 09 & 09 & 08 & 05 & 05 & 03 & 02 & 01 & 01 \\
\hline
\end{tabular}




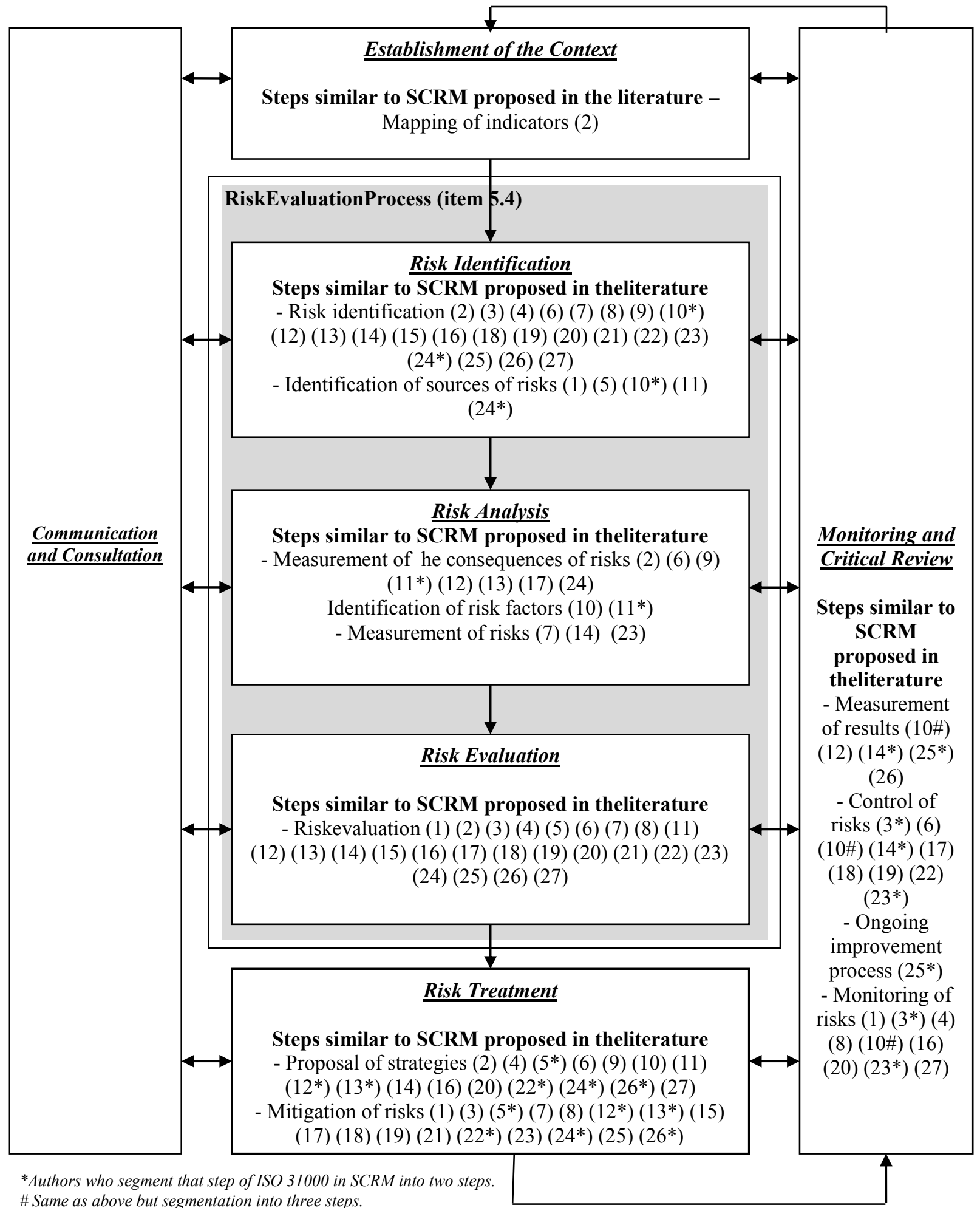

Fig. 17. Analysis of the steps proposed for SCRM, according to the risk management process of ISO 31000.

Source: Authors (2016)

\subsection{Application of AHP to prioritize risk assessment tools to automotive supply chain}

In this section, we present the results from the AHP application to automotive supply chain to identify/prioritize the tools for risk assessment, based on the applied questionnaires.
Each Expert classified each of the 13 tools, as seen in the Expert 1 example (Chart 3), based on their priority perception. Arithmetic mean was used to aggregate the overall Expert priorities (Forman and Peniwati, 1998) from different companies, as seen in Chart 4.

As it can be seen in the last column in Chart 4, "Cost/benefit analysis", "business impact analysis", "Scenario analysis", 


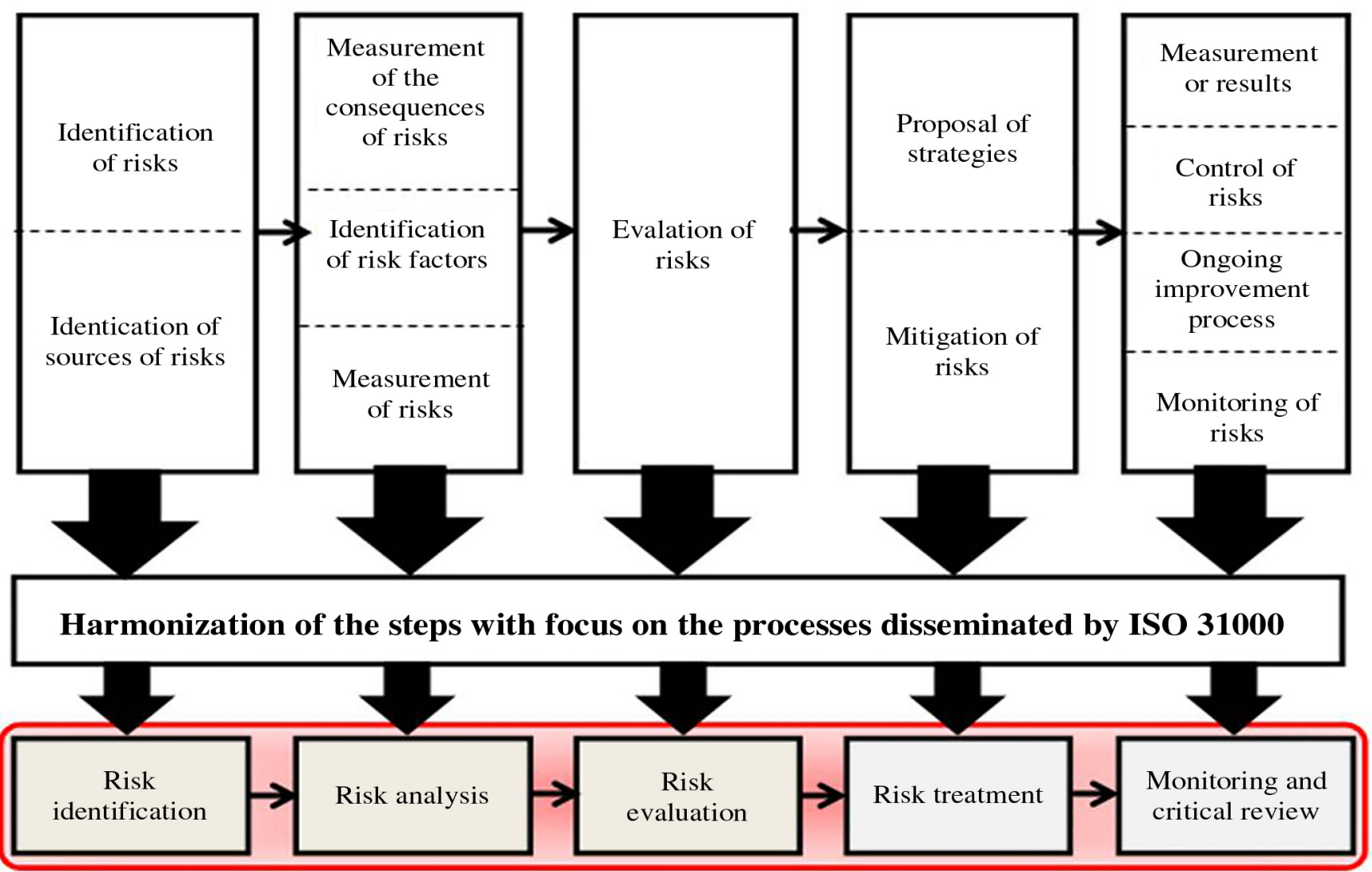

Fig. 18. Systematic process for carrying out SCRM.

Source: Authors (2016)

Chart 3

Priorities of risk assessment tools according to Expert 1.

\begin{tabular}{|c|c|c|c|c|}
\hline Tool & Risk identification & Risk analysis & Risk evaluation & Overall priority \\
\hline HAZOP & $56 \%$ & $11 \%$ & $4 \%$ & $23 \%$ \\
\hline Environmental risk assessment & $11 \%$ & $33 \%$ & $11 \%$ & $19 \%$ \\
\hline SWIFT & $33 \%$ & $11 \%$ & $4 \%$ & $16 \%$ \\
\hline Scenario analysis & $11 \%$ & $33 \%$ & $11 \%$ & $19 \%$ \\
\hline Business impact analysis & $33 \%$ & $100 \%$ & $33 \%$ & $56 \%$ \\
\hline FMEA & $11 \%$ & $33 \%$ & $11 \%$ & $19 \%$ \\
\hline Cause and consequence analysis & $11 \%$ & $100 \%$ & $33 \%$ & $48 \%$ \\
\hline HRA & $4 \%$ & $33 \%$ & $11 \%$ & $16 \%$ \\
\hline Reliability centred maintenance & $11 \%$ & $11 \%$ & $33 \%$ & $19 \%$ \\
\hline FN curve & $33 \%$ & $33 \%$ & $100 \%$ & $56 \%$ \\
\hline Risk indices & $100 \%$ & $11 \%$ & $33 \%$ & $48 \%$ \\
\hline Consequence/probability matrix & $33 \%$ & $33 \%$ & $33 \%$ & $33 \%$ \\
\hline Cost/benefit analysis & $100 \%$ & $100 \%$ & $100 \%$ & $100 \%$ \\
\hline
\end{tabular}

Source: Authors (2016)

Chart 4

Aggregated priorities of risk assessment tools.

\begin{tabular}{|c|c|c|c|c|c|c|}
\hline TOOL & E1 & E2 & E3 & E4 & E5 & AGGREGATE \\
\hline HAZOP & $23 \%$ & $10 \%$ & $14 \%$ & $26 \%$ & $33 \%$ & $21 \%$ \\
\hline Environmental risk assessment & $19 \%$ & $93 \%$ & $8 \%$ & $56 \%$ & $7 \%$ & $37 \%$ \\
\hline SWIFT & $16 \%$ & $13 \%$ & $20 \%$ & $29 \%$ & $3 \%$ & $16 \%$ \\
\hline Scenario analysis & $19 \%$ & $100 \%$ & $24 \%$ & $42 \%$ & $6 \%$ & $38 \%$ \\
\hline Business impact analysis & $56 \%$ & $100 \%$ & $24 \%$ & $45 \%$ & $22 \%$ & $49 \%$ \\
\hline FMEA & $19 \%$ & $11 \%$ & $100 \%$ & $8 \%$ & $32 \%$ & $34 \%$ \\
\hline Cause and consequence analysis & $48 \%$ & $56 \%$ & $29 \%$ & $4 \%$ & $26 \%$ & $33 \%$ \\
\hline HRA & $16 \%$ & $6 \%$ & $10 \%$ & $13 \%$ & $13 \%$ & $12 \%$ \\
\hline Reliability centred maintenance & $19 \%$ & $16 \%$ & $5 \%$ & $5 \%$ & $38 \%$ & $17 \%$ \\
\hline FN curve & $56 \%$ & $8 \%$ & $10 \%$ & $2 \%$ & $17 \%$ & $19 \%$ \\
\hline Risk indices & $48 \%$ & $63 \%$ & $10 \%$ & $2 \%$ & $24 \%$ & $29 \%$ \\
\hline Consequence/probability matrix & $33 \%$ & $10 \%$ & $29 \%$ & $2 \%$ & $51 \%$ & $25 \%$ \\
\hline Cost/benefit analysis & $100 \%$ & $78 \%$ & $39 \%$ & $9 \%$ & $73 \%$ & $60 \%$ \\
\hline
\end{tabular}

Bold characters were used to highlight the top 6 risk tools. (as described/detailed in the paragraph down below).

Source: Authors (2016) 
"Environmental risk assessment", "FMEA", and "Cause and consequence analysis" are the top six risk assessment tools. Thus, we infer that these six ISO31000 tools should be studied, understood and applied in the three dimensions (Risk identification, risk analysis, and risk evaluation) to develop a SCRM procedure for the automotive sector.

\section{Conclusions}

In this article, we applied the SLR method to analyze 27 studies that have addressed the constructs and steps to carry out SCRM. Because of the different conceptual bases regarding the steps that should be followed in undertaking SCRM, we sought to learn whether it is possible to adopt the ISO 31000 standard as a uniform process for SCRM.

As intermediate results, with respect to ISO 31000 standard, we found that $100 \%$ of the articles analyzed make allusion to the risk identification and risk treatment steps; $92.59 \%$ cover the risk evaluation step (which in some cases also includes the risk analysis step); and $66.67 \%$ of the studies address risk monitoring in SCRM.

As final results, we found that the steps mentioned by the authors of the articles examined converged to one of the phases of the risk management process (Section 5.4 of ISO 31000:2009 standard), as shown in Chart 2 and Fig. 17. In addition, we have proposed the application of the AHP to prioritize the tools for risk assessment listed in ISO31000 to be applied to the SCRM, as described in the automotive supply chain study.

Therefore, we believe the four objectives of this study were achieved, by: i) examining the risk management steps proposed by researchers about SCRM; ii) harmonizing these steps; iii) analyzing the correspondence of these harmonized steps of SCRM with the ISO 31000 standard; and, (iv) Proposing a general procedure to perform the SCRM, through the identification of tools to be used in an application of the general procedure to an automobile supply chain. Consequently, the general objective of the study, which was to evaluate whether the ISO 31000 standard can be utilized as a systematic process for SCRM and, beyond that, proposing a pathway to companies develop their procedures to manage risks in supply chains based on the standard, was also achieved.

Despite the results obtained here, we point out that SCRM is a particular task that is inherent to each organization, involving endogenous and exogenous questions that determine the level of criticality, and thus the design and structure of the risk management process. Based on different needs and contexts, it is not feasible to develop a procedure to manage risks in supply chain that would fulfill all companies' needs and requirements. Therefore, firms that have already adopted a formal risk management model for their supply chains can conduct a critical analysis of their practices, based on the findings presented here.

As recommendations for future research, we suggest that other MCDM models, as Analytic Network Process - ANP (Santos et al., 2015) could be used prioritize the tools to risk assessment listed in ISO31000. We also suggest that the procedure to select tools and techniques for risk assessment be applied in other industries, such as aeronautics, electronics, construction, etc.

\section{References}

Ataseven, C., Prajogo, D.I., Nair, A., 2014. ISO 9000 Internalization and organizational commitment-Implications for process improvement and operational performance. IEEE Trans. Eng. Manag. 61 (1), 5-17.

Blome, C., Schoenherr, T., 2011. Supply chain risk management in financial crises: a multiple case-study approach. Int. J. Prod. Econ. 134 (1), 43-57.

Blos, M.F., Quaddus, M., Wee, H.M. Watanabe, K., 2009. Supply chain risk management (SCRM): a case study on the automotive and electronic industries in Brazil. Supply Chain Manag. An Int. J. 14 (4), 247-252.

Bouzon, M., Miguel, P.A.C., Rodriguez, C.M.T., 2014. Managing end of life products: a review of the literature on reverse logistics in Brazil. Manag. Environ. Quality An Int. J. 25 (5), 564-584.

Chopra, S., Sodhi, M., 2004. Managing risk to avoid supply chain breakdown. MIT Sloan Manag. Rev. 46 (1), 53-61.

Christopher, M., Lee, H., 2004. Mitigating supply chain risk through improved confidence. Int. J. Phys. Distrib. Logist. Manag. 34 (5), 388-396.

Cohen, M.A., Kunreuther, H., 2007. Operations risk management: overview of Paul Kleindorfer's contributions. Prod. Oper. Manag. 16 (5), 525-541.

Colicchia, C., Strozzi, F., 2012. Supply chain risk management: a new methodology for a systematic literature review. Supply Chain Manag. An Int. J. 17 (4) 403-418.

Elleuch, H., Hachicha, W., Chabchoub, H., 2014. A combined approach for supply chain risk management: description and application to a real hospital pharmaceutical case study. J. Risk Res. 17 (5), 641-663.

Everett, C., 2011. A risk business: ISO 31000 and 27005 unwrapped. Comput. Fraud Secur. 2011 (2), 5-7.

Faisal, M.N., Banwet, D.K., Shankar, R., 2006. Supply chain risk mitigation: modeling the enablers. Bus. Process Manag. J. 12 (4), 535-552.

Forman, E., Peniwati, K., 1998. Aggregating individual judgments and priorities with the analytic hierarchy process. Eur. J. Operational Res. 108 (1998), 165-169.

Gaonkar, R.S., Viswanadham, N., 2007. Analytical framework for the management of risk in supply chains. IEEE Trans. Automation Sci. Eng. 4 (2), 265-273.

Ghadge, A., Dani, S., Kalawsky, R., 2012. Supply chain risk management: present and future scope. Int. J. Logist. Manag. 23 (3), 313-339.

Giannakis, M., Louis, M., 2011. A multi-agent based framework for supply chain risk management. J. Purch. Supply Manag. 17 (1), 23-31.

Guo, Y., 2011. Research on knowledge-oriented supply chain risk management system model. J. Manag. Strategy 2 (2), 72-77.

Hahn, G.J., Kuhn, H., 2012. Value-based performance and risk management in supply chains: a robust optimization approach. Int. J. Prod. Econ. 139 (1), 135-144.

Hallikas, J., Karvonen, I., Pulkkinen, U., Virolainen, V., Tuominen, M., 2004. Risk management processes in supplier networks. Int. J. Prod. Econ. 90 (1), 47-58.

Harland, C., Brenchley, R., Walker, H., 2003. Risk in supply networks. J. Purch. Supply Manag. 9 (2), 51-62.

Hendricks, K.B., Singhal, V.R., Zhang, R.R., 2009. The effect of operational slack, diversification, and vertical relatedness on the stock market reaction to supply chain disruptions. J. Oper. Manag. 27 (3), 233-246.

Hunt, G.T.M., Craighead, C.W., Ketchen Jr., D.J., 2010. Risk uncertainty and supply chain decisions: a real options perspective. Decis. Sci. 41 (3), 435-458.

Ibanez, A.J.P., Bernal, J.M.M., Diego, M.J.C., Sanchez, F.J.A., 2016. Expert system for predicting buildings service life under ISO 31000 standard. Application in architectural heritage. J. Cult. Herit. 18, 209-218.

Ishizaka, A., Pearman, C., Nemery, P., 2012. AHP Sort: an AHP based method for sorting problems. Int. J. Prod. Res. 50 (17), 4767-4784.

ISO, 2009a. Risk Management- Principles and Guidelines: ISO 31000, p. 2009.

ISO, 2009b. Risk Management — Risk Assessment Techiques: ISO 31010, p. 2009.

Jia, F., Rutherford, C., 2010. Mitigation of supply chain relational risk caused by cultural differences between China and the West. Int. J. Logist. Manag. 21 (2), $251-270$.

Jurado, P.J.M., Fuentes, J.M., 2013. Lean management, supply chain management and sustainability: a literature review. J. Clean. Prod. 85, 134-150.

Juttner, U., 2005. Supply chain risk management: understanding the business requirements from a practitioner perspective. Int. J. Logist. Manag. Emerald Insight 16 (1), 120-141.

Juttner, U., Peck, Christopher, H., 2003. Supply chain risk management: outlining an agenda for future research. Int. J. Logist. Res. Appl. 6 (4), 197-210.

Kern, D., Moser, R., Hartmann, E., Moder, M., 2012. Supply risk management: model development and empirical analysis. Int. J. Phys. Distrib. Logistics Manag. 42 (1) 60-82.

Khan, O., Burnes, B., 2007. Risk and supply chain management: creating a research agenda. Int. J. Logist. Manag. 18 (2), 197-216.

Kleindorfer, P.R., Saad, G.H., 2005. Managing disruption risks in supply chains. Prod. Oper. Manag. 14 (1), 53-68.

Lalonde, C., Boiral, O., 2012. Managing risks through ISO 31000: a critical analysis. Risk Manag. 14 (4), 272-300.

Lambert, D.M., Cooper, M.C., 2000. Issues in supply chain management. Ind. Mark. Manag. 29 (1), 65-83.

Lavastre, O., Gunasekaran, A., Spalanzani, A., 2012. Supply chain risk management in French companies. Decis. Support Syst. 52 (4), 828-838.

Mabrouki, C., Bentaleb, F., Mousrij, A., 2014. A decision support methodology for risk management within a port terminal. Saf. Sci. 63, 124-132.

Manuj, I., Mentzer, J.T., 2008. Global supply chain risk management. J. Bus. Logist. 29 (1), 133-155.

Marija, M., Ivan, B., Dusan, R., 2015. Supply chain risk management using software tool. Acta Polytech. Hung. 12 (4), 167-182.

Matook, S., Lasch, R., Tamaschke, R., 2009. Supplier development with benchmarking as part of a comprehensive supplier risk management framework. Int J. Oper. Prod. Manag. 29 (3), 241-267.

Mentzer, T.J., Kahn, K.B., 1995. A framework of logistics research. J. Bus. Logist. 16 (1) 231-250.

Meredith, J., 1993. Theory building through conceptual methods. Int. J. Oper. Prod. Manag. 13 (5), 3-11.

Narasimhan, R., Talluri, S., 2009. Perspectives on risk management in supply chains. J. Oper. Manag. 27 (2), 114-118 
Neves, A.A.S., Pinardi, N., Martins, F., Janeiro, J., Samaras, A., Zodiatis, G., Dominicis, M., 2015. Towards a common oil spill risk assessment framework adapting ISO 31000 and addressing uncertainties. J. Environ. Manag. 159 (15) 158-168.

Norrman, A., Jansson, U., 2004. Ericsson's proactive supply chain risk management approach after a serious sub-supplier accident. Int. J. Phys. Distrib. Logist. Manag. 34 (5), 434-456.

Oehmen, J., Ziegenbein, A., Alard, R., Schonsleben, P., 2009. System-oriented supply chain risk management. Prod. Plan. Control 20 (4), 343-361.

O'kane, J.F., Spenceley, J.R., Taylor, R., 2000. Simulation as an essential tool for advanced manufacturing technology problems. J. Mater. Process. Technol. 107 (1-3), 412-424.

Pawliczek, A., Piszczur, R., 2013. Effect of management systems ISO 9000 and ISO14000 on enterprises awareness of sustainability priorities. E+M Econ. Manag. 16 (2), 66-80.

Pfohl, H.C., Köhler, H., Thomas, D., 2010. State of the art in supply chain risk management research: empirical and conceptual findings and a roadmap for the implementation in practice. Logist. Res. 2 (1), 33-44.

Pujawan, I.N., Geraldin, L.H., 2009. House of risk: a model for proactive supply chain risk management. Bus. Process Manag. J. 15 (6), 953-967.

Rangel, D.A., Oliveira, T.K., Leite, M.S.A., 2015. Supply chain risk classification: discussion and proposal. Int. J. Prod. Res. 53 (22), 6868-6887.

Rao, S., Goldsby, T.J., 2009. Supply chain risks: a review and typology. Int. J. Logist. Manag. 20 (1), 97-123.

Ritchie, B., Brindley, C., 2007. Supply chain risk management and performance: a guiding framework for future development. Int. J. Oper. Prod. Manag. 27 (3), 303-322.

Rotaru, K., Wilkin, C., Ceglowski, A., 2014. Analysis of SCOR's approach to supply chain risk management. Int. J. Oper. Prod. Manag. 34 (10), 1246-1268.

Saaty, T.L., 1994. How to make a decision: the analytic hierarchy process. Interfaces 24 (6), 19-43.

Saaty, T.L., Shih, H.S., 2009. Structures in decision making: on the subjective geometry of hierarchies and networks. Eur. J. Operational Res. 199 (3), 867-872.

Saaty, T.L., Vargas, L.G., Whitaker, R., 2009. Addressing with brevity criticism of the analytic hierarchy process. Int. J. Anal. Hierarchy Process 1 (2), 121-134.

Salgado, E.G., Salomon, V.A.P., Mello, C.H.P., 2012. Analytic hierarchy prioritisation of new product development activities for electronics manufacturing. Int. J. Prod. Res. 50 (17), 4860-4866.

Santos, M.A.R., Salomon, V.A.P., Marins, F.A.S., 2015. Analytic network process and balanced scorecard applied to the performance evaluation of public health systems. Pesqui. Oper. 35 (2), 353-361.

Seuring, S., Muller, M., 2008. From a literature review to a conceptual framework for sustainable supply chain management. J. Clean. Prod. 16 (15), 1699-1710.

Singhal, P., Agarwal, G., Mittal, M.L., 2011. Supply chain risk management: review, classification and future research directions. Int. J. Bus. Sci. Appl. Manag. 6 (3),
$15-42$.

Sodhi, M.S., Son, B., Tang, C., 2012. Researchers' perspectives on supply chain risk management. Prod. Oper. Manag. 21 (1), 1-13.

Thorpe, R., Holt, R., Macpherson, A., Pittaway, L., 2005. Using knowledge within small and medium-sized firms: a systematic review of the evidence. Int. J. Manag. Rev. 7 (4), 257-281.

Tramarico, C.L., Salomon, V.A.P., Marins, F.A.S., 2017. Multi-criteria assessment of a supply chain management training considering green issues. J. Clean. Prod. 142 (1), 249-256.

Tranfield, D., Denyer, D., Smart, P., 2003. Towards a methodology for developing evidence-informed management knowledge by means of systematic review. Br. J. Manag. 14 (3), 207-222.

Trkman, P., Mccormack, K., 2009. Supply chain risk in turbulent environments: a conceptual model for managing supply chain network risk. Int. J. Prod. Econ. 119 (2), 247-258.

Tummala, R., Schoenherr, T., 2011. Assessing and managing risks using the supply chain risk management process (SCRMP). Supply Chain Manag. An Int. J. 16 (6), 474-483.

Tuncel, G., Alpan, G., 2010. Risk assessment and management for supply chain networks: a case study. Comput. Industry 61 (3), 250-259.

Wagner, S., Bode, C., 2008. An empirical examination of supply chain performance along several dimensions of risk. J. Bus. Logist. 29 (1), 307-325.

Wallenius, J., Dyer, J.S., Fishburn, P.C., Steuer, R.E., Zionts, S., Deb, K., 2008. Multiple criteria decision making, multi attribute utility theory: recent accomplishment sand what lies ahead. Manag. Sci. 54 (7), 1336-1349.

Wang, H., Hsu, F., 2009. An integrated operation module for individual risk management. Eur. J. Oper. Res. 198 (2), 610-617.

Webster, J., Watson, R.T., 2002. Analyzing the past to prepare for the future: writing a literature review. MIS Q. $26(2), 8-23$.

White, D., 1995. Application of system thinking to risk management: a review of the literature. Manag. Decis. 33 (10), 35-45.

Wieland, A., Wallenburg, C.M., 2012. Dealing with supply chain risks: linking risk management practices and strategies to performance. Int. J. Phys. Distrib. Logist. Manag. 42 (10), 887-905.

Wu, T., Blackhurst, J., Chidambaram, V., 2006. A model for inbound supply risk analysis. Comput. Industry 57 (4), 350-365.

Xia, D., Chen, B., 2011. A comprehensive decision-making model for risk management of supply chain. Expert Syst. Appl. 38 (5), 4957-4966.

Zafiropoulos, L., Metaxiotis, K., Askounis, D., 2005. Dynamic risk management system for the modeling, optimal adaptation and implementation of an ERP system. Inf. Manag. Comput. Secur. 13 (3), 212-234.

Zsidisin, G., Ragatz, G.L., Melnyk, S.A., 2005. An institutional theory perspective of business continuity planning for purchasing and supply management. Int. J. Prod. Res. 43 (16), 3401-3420. 